\title{
Beta-hydroxybutyrate (3-OHB) can influence the energetic phenotype of breast cancer cells, but does not impact their proliferation and the response to chemotherapy or radiation
}

Catharina Bartmann', Sudha R. Janaki Raman², Jessica Flöter², Almut Schulze², Katrin Bahlke', Jana Willingstorfer', Maria Strunz ${ }^{1}$, Achim Wöckel ${ }^{1}$, Rainer J. Klement ${ }^{3}$, Michaela Kapp ${ }^{1}$, Cholpon S. Djuzenova ${ }^{4}$, Christoph Otto ${ }^{5}$ and Ulrike Kämmerer ${ }^{1 *}$

\begin{abstract}
Background: Ketogenic diets (KDs) or short-term fasting are popular trends amongst supportive approaches for cancer patients. Beta-hydroxybutyrate (3-OHB) is the main physiological ketone body, whose concentration can reach plasma levels of 2-6 mM during KDs or fasting. The impact of 3-OHB on the biology of tumor cells described so far is contradictory. Therefore, we investigated the effect of a physiological concentration of $3 \mathrm{mM} 3-\mathrm{OHB}$ on metabolism, proliferation, and viability of breast cancer (BC) cells in vitro.

Methods: Seven different human BC cell lines (BT20, BT474, HBL100, MCF-7, MDA-MB 231, MDA-MB 468, and T47D) were cultured in medium with $5 \mathrm{mM}$ glucose in the presence of $3 \mathrm{mM} 3-\mathrm{OHB}$ at mild hypoxia (5\% oxygen) or normoxia (21\% oxygen). Metabolic profiling was performed by quantification of the turnover of glucose, lactate, and $3-\mathrm{OHB}$ and by Seahorse metabolic flux analysis. Expression of key enzymes of ketolysis as well as the main monocarboxylic acid transporter MCT2 and the glucose-transporter GLUT1 was analyzed by RT-qPCR and Western blotting. The effect of 3-OHB on short- and long-term cell proliferation as well as chemo- and radiosensitivity were also analyzed.
\end{abstract}

Results: 3-OHB significantly changed the oxygen consumption rate (OCR) and extracellular acidification rate (ECAR) in BT20 cells resulting in a more oxidative energetic phenotype. MCF-7 and MDA-MB 468 cells had increased ECAR only in response to $3-\mathrm{OHB}$, while the other three cell types remained uninfluenced. All cells expressed MCT2 and GLUT1, thus being able to uptake the metabolites. The consumption of 3-OHB was not strongly linked to mRNA overexpression of key enzymes of ketolysis and did not correlate with lactate production and glucose consumption. Neither 3-OHB nor acetoacetate did interfere with proliferation. Further, 3-OHB incubation did not modify the response of the tested $\mathrm{BC}$ cell lines to chemotherapy or radiation.

(Continued on next page)

\footnotetext{
* Correspondence: frak057@mail.uni-wuerzburg.de

${ }^{1}$ Department of Obstetrics and Gynaecology, University Hospital of

Würzburg, Josef-Schneider-Str. 4, 97080 Würzburg, Germany

Full list of author information is available at the end of the article
}

(c) The Author(s). 2018 Open Access This article is distributed under the terms of the Creative Commons Attribution 4.0 International License (http://creativecommons.org/licenses/by/4.0/), which permits unrestricted use, distribution, and reproduction in any medium, provided you give appropriate credit to the original author(s) and the source, provide a link to the Creative Commons license, and indicate if changes were made. The Creative Commons Public Domain Dedication waiver (http://creativecommons.org/publicdomain/zero/1.0/) applies to the data made available in this article, unless otherwise stated. 
(Continued from previous page)

Conclusions: We found that a physiological level of 3-OHB can change the energetic profile of some BC cell lines. However, 3-OHB failed to influence different biologic processes in these cells, e.g., cell proliferation and the response to common breast cancer chemotherapy and radiotherapy. Thus, we have no evidence that 3-OHB generally influences the biology of breast cancer cells in vitro.

Keywords: Ketogenic diet, $\beta$-Hydroxybutyrate, Ketone bodies, Breast cancer, Seahorse, Metabolic profile, Chemotherapy, lonizing radiation

\section{Background}

Breast cancer $(\mathrm{BC})$ is one of the most common cancers and affects about one in eight women during their lifetime [1]. In general, modern BC therapy includes different therapeutic approaches, such as surgical removal of the tumor, chemotherapy, radiation, and hormone therapy [2]. In addition to these conventional therapies, a large number of patients seek supportive therapies like specific diets to improve their outcome. The correlation between different types of diet and the incidence and progression of cancer is increasingly becoming the focus of research [3-7]. In this respect, avoiding carbohydrates to specifically "starve cancer cells" is the most popular trend amongst "cancer diets." The rationale for this dietary regime is often based on the "Warburg effect," which describes the preferential fermentation of glucose to lactate even under availability of sufficient oxygen $[8,9]$. Therefore, reducing carbohydrate intake and thus lowering blood glucose seems to be a promising strategy for cutting cancer off from glucose supply [10-12].

Besides fasting, the strictest form of such a "very low carb" diet is called the ketogenic diet (KD). The KD is characterized by consuming the predominant proportion of calories from fat, balancing those derived from protein and thus consuming very few calories from glucose or other carbohydrates. Different KD regimens were shown to be safe and well tolerated in a variety of malignancies [13-19] and lead to the metabolic state of a physiological ketosis [20]. During ketosis, the "ketone bodies" acetoacetate $(\mathrm{AcAc})$ and $\mathrm{D}-\beta$-hydroxybutyrate (R-3-hydroxybutyrate: $3-\mathrm{OHB})$ are predominantly produced in the liver and can be detected in the peripheral blood and urine above normal levels [21]. 3-OHB is found at similar or higher concentrations than AcAc and therefore, considered the principal "ketone body." In humans, the median concentration of 3-OHB in plasma reaches approximately $3 \mathrm{mM}$ under short-term fasting conditions [22], up to $6 \mathrm{mM}$ during long-term starvation [23] and regularly at least $2 \mathrm{mM}$ under a ketogenic diet [24].

$3-\mathrm{OHB}$ is transported into cells via monocarboxylic acid transporters (MCT). The isoforms MCT1, MCT2, and MCT4 can transport lactate and ketone bodies across the cell membrane $[25,26]$. Here, MCT2 has the highest affinity for $3-\mathrm{OHB}$, whereas $\mathrm{MCT} 1$ and 4 have a higher affinity for lactate [27, 28]. In mitochondria, $3-\mathrm{OHB}$ is degraded via ketolysis into acetyl-CoA, which then is metabolized within the Krebs cycle and the respiratory chain to generate energy [29-32]. Since the oxidation of 3-OHB generates more energy per mol oxygen used compared to glucose, it is sometimes labeled a "superfuel" [33]. However, cells need functioning mitochondria as well as sufficient oxygen supply to generate energy from 3-OHB. The latter is hampered in the hypoxic microenvironment of larger tumors, which has already been shown in vivo for breast cancer tissue in patients [34].

There are somewhat contradicting results regarding the effect of 3-OHB on growth and biology of tumor cells cultured in vitro and in experimental tumors in mice. In some studies, ketone bodies seem to be associated with cancer progression, metastasis, and poor clinical outcome $[35,36]$. In contrast, it was shown that a ketogenic diet significantly reduces tumor growth in mice [37, 38]. Further, an antiproliferative effect of 3-OHB was already shown for different cancer cells, such as glioblastoma and tumor stem cells [37], melanoma, cervical carcinoma, or neuroblastoma [39-41]. Several studies also described a significant delay of tumor growth in mice and humans in a systemic ketosis $[16,18,37,38,40,42-49]$. In this respect, Rodrigues and coworkers reported evidence for a " $\beta$-hydroxybutyrate paradox" [50]. They postulated that the effect of 3-OHB on cancer growth would depend on the tumor's energetic phenotype. Thus, "oxidative cells" would use 3-OHB as an additional energy source so that tumors with predominantly "oxidative cells" increase their growth when this metabolite is available. Other cells with a more "glycolytic, Warburg-like phenotype" would be unable to metabolize $3-\mathrm{OHB}$ in which case it could accumulate intracellularly and inhibit tumor growth via signaling and epigenetic mechanisms [50].

In view of this preclinical pro- and contra evidence and the fact that increasing numbers of patients are adopting a ketogenic diet or short-term fasting during oncological therapy, we studied the impact of 3-OHB on seven different $\mathrm{BC}$ cell lines in vitro. Here, we initially analyzed the energetic profile of these cells and correlated this to the effect of $3-\mathrm{OHB}$ on cell proliferation. 
Further, we investigated the possibility of synergism between ketosis and radio- or chemotherapy [51]. To mimic a physiological state of metabolites found in the circulation of patients performing a $\mathrm{KD}$, we performed experiments with $3 \mathrm{mM} 3-\mathrm{OHB}$, representing pronounced ketosis, and $5 \mathrm{mM}$ glucose, typical for the blood glucose level found in persons on a KD (range 4.9-5.2 mM) [19, 52-57]. Furthermore, we investigated cells at both an oxygen supply of $5 \%$ oxygen (= $5 \mathrm{kPA})$, a typical mean concentration between well-vascularized benign breast tissue (6.5 kPA) and non-hypoxic tumor regions (3.2-4.7 $\mathrm{kPA})$ in vivo [58] and $21 \%$ oxygen (21 kPA), as a common condition used in cell culture.

\section{Methods}

\section{Breast cancer cell lines and culture}

The BC cell lines BT20, BT474, HBL100, MCF-7, MDA-MB 231, MDA-MB 468, and T47D were obtained from Cell Lines Service GmbH (CLS; Eppelheim, Germany), and their receptor status, subtype, and mutation status are summarized in Table 1 [59-65]. The BT474 and the MDA-MB 231 cell lines were purchased directly from CLS for the experiments and used at low passage. All other cell lines were authenticated via genetic profiling of SRT loci by CLS before running the experiments. Aliquots of the cell lines were freshly cultured from frozen samples in
75- $\mathrm{cm}^{2}$ cell culture flasks (TPP, Trasadingen, Switzerland) in Dulbecco's modified Eagle's medium (DMEM)/Hams F12 (1:1) medium (Gibco, ThermoFisher Scientific, Darmstadt, Germany) supplemented with $10 \%$ fetal calf serum (FCS; Biochrom, Berlin, Germany) and 50 ng/ml Gentamycin (Sigma-Aldrich, Munich, Germany) in the presence of $5 \% \mathrm{CO}_{2}$ and $21 \%$ oxygen, respectively.

\section{Turnover of metabolites}

For quantification of glucose, lactate, and 3-OHB metabolism, cells were seeded and cultured at conditions described in the cell proliferation assay. After 5 days, supernatants were collected and the levels of 3-OHB were analyzed by the PrecisionXceed ${ }^{\circledR}$ instrument with the corresponding test strips FreeStyle Precision ${ }^{\circ}$ $\beta$-Ketone (Abbott, Wiesbaden, Germany). The concentrations of glucose and lactate were measured with the Cobas 8000 modular analyzer series (Roche Diagnostics; Mannheim, Germany) at the central laboratory of the University Hospital of Würzburg. Concentrations of metabolites were expressed in millimolar per optical density (OD) of crystal violet dye extracts in each well at day 3 or 5 of culture. The amount of solubilized dye in OD is directly proportional to the cell number. Therefore, after removing the supernatant carefully for metabolite quantification, adherent cells were fixed with $100 \mu \mathrm{l}$ methanol

Table 1 Subtype of the breast cancer cell lines used in the experiments

\begin{tabular}{|c|c|c|c|c|c|c|}
\hline \multirow[t]{2}{*}{ Cell line } & \multicolumn{3}{|c|}{ Receptor } & \multirow[t]{2}{*}{ Subtype } & \multirow[t]{2}{*}{ Ref. } & \multirow[t]{2}{*}{ Mutations* } \\
\hline & ER & PR & Her2 & & & \\
\hline \multirow[t]{2}{*}{ BT20 } & - & $(-)$ & $\mathrm{np}$ & Basal A & [60] & ATM; BRCA2; CBLB; CDKN2A; COL1A1; RAP1GDS1; RB1; PIK3CA TP53 \\
\hline & 0 & 0 & $0-1$ & Basal & [61] & \\
\hline \multirow[t]{3}{*}{ BT474 } & + & $(+)$ & + & Luminal & [60] & EPS15; HIST1H3B; NSD1; PIK3CA; PPP2R1A; RHOA; TP53 \\
\hline & 0 & 8 & $3+$ & Luminal B & [61] & \\
\hline & + & $+/-$ & + & Luminal B & [59] & \\
\hline HBL100 & - & $(-)$ & $\mathrm{np}$ & Basal B & [60] & $\mathrm{np}$ \\
\hline \multirow[t]{3}{*}{ MCF-7 } & + & $(+)$ & $\mathrm{np}$ & Luminal & [60] & ATP2B3; CDKN2A; EP300; ERBB4; MAP3K13; PIK3CA \\
\hline & 6 & 6 & $0-1$ & Luminal A & [61] & \\
\hline & + & $+/-$ & - & Luminal A & [59] & \\
\hline \multirow[t]{2}{*}{ MDA-MB 231} & - & $(-)$ & $\mathrm{np}$ & Basal B & [60] & BRAF; CD79A; KRAS; CNKN2A; NF2; PBRM1; PDGFRA; TP53 \\
\hline & 0 & 0 & $0-1+$ & Basal & [61] & \\
\hline \multirow[t]{3}{*}{ MDA-MB 468} & $(-)$ & $(-)$ & $\mathrm{np}$ & Basal A & [60] & CACNA1D; INPP4B; PTEN; RB1; TP53 \\
\hline & 0 & 0 & 0 & Basal & [61] & \\
\hline & - & - & - & Basal & [59] & \\
\hline \multirow[t]{2}{*}{ T47D } & + & $(+)$ & $\mathrm{np}$ & Luminal & [60] & ACVR1; ARID1A; PIK3CA; TP53 \\
\hline & + & + & - & Luminal A & [59] & \\
\hline
\end{tabular}

The subtype of the breast cancer cell lines used was classified before by gene expression profile and the expression of the estrogen (ER), progesterone (PR), and human epidermal growth factor receptor 2 (Her2) receptor. The abbreviations of receptors and breast cancer subtype classification shown here are published [59-61]. Semiquantified receptor status: results with "-", "(-)", "0", and "0-1+" are classified as negative and results with " + ", " $(+)$ ", " $+/-$ ", 6, and 8 are classified as positive for receptor expression (also summarized by [62]) $n p$ not published

*Mutations shown here are described by [63-65] 
(Sigma-Aldrich) for $10 \mathrm{~min}$ at room temperature (RT) and then dried. Cells were stained by incubation in $100 \mu \mathrm{l}$ crystal violet solution per well $(0.4 \%$ crystal violet [Merck, Darmstadt, Germany] in 1:3 methanol: phosphate-buffered saline) for $10 \mathrm{~min}$ at RT and then washed several times with distilled water. Crystal violet was extracted from cells with $100 \mu \mathrm{l}$ of $10 \%$ acetic acid per well on a plate shaker for $30 \mathrm{~min}$, and OD was determined at $570 \mathrm{~nm}$ by using a standard ELISA-Plate reader.

\section{Energetic profiling by Seahorse technique}

The oxygen consumption rate (OCR) and extracellular acidification rate (ECAR) were analyzed with the Seahorse XF Cell Mito Stress Test (Part \#103015-100; Agilent Technologies, Santa Clara, CA, USA) in a Seahorse XFe96 Analyzer (Agilent Technologies). The day before the experiment, 40,000 cells per well were plated in a 96-well Seahorse plate in $100 \mu \mathrm{l}$ DMEM/10\% FCS/Gentamycin/5 mM glucose medium with or without $3 \mathrm{mM} 3-\mathrm{OHB}$ (sodium-hydroxybutyrate, Sigma-Aldrich). The Agilent Seahorse XFe96 Sensor Cartridge was hydrated with $200 \mu \mathrm{l} /$ well of XF calibrant solution overnight in a non- $\mathrm{CO}_{2}$ incubator at $37{ }^{\circ} \mathrm{C}$. On the day of the experiment, $100 \mathrm{ml}$ of Seahorse assay medium containing $1 \mathrm{mM}$ pyruvate, $2 \mathrm{mM}$ glutamine, and $5 \mathrm{mM}$ glucose was prepared. The $\mathrm{pH}$ of the pre-warmed $\left(37^{\circ} \mathrm{C}\right)$ medium was adjusted to 7.4 with $0.1 \mathrm{~N}$ $\mathrm{NaOH}$. Twenty milliliters of the assay medium was used to prepare $3 \mathrm{mM} 3-\mathrm{OHB}$, and the $\mathrm{pH}$ was readjusted to 7.4 with $0.1 \mathrm{~N} \mathrm{HCl}$. Cells were washed twice with $200 \mu \mathrm{l}$ of the corresponding Seahorse medium and incubated in $175 \mu \mathrm{l}$ of the respective Seahorse medium per well in a non- $\mathrm{CO}_{2}$ incubator at $37^{\circ} \mathrm{C}$ for $1 \mathrm{~h}$. Meanwhile, the Seahorse sensor cartridge ports were loaded with $25 \mu \mathrm{l}$ of inhibitors to have a final concentration of $2 \mu \mathrm{M}$ oligomycin (port A, Calbiochem), $1 \mu \mathrm{M}$ FCCP (port B, Sigma-Aldrich), and $0.5 \mu \mathrm{M}$ rotenone/antimycin A (port C, Sigma-Aldrich). The experimental design was setup using the WAVE software program, and measurements were performed in the Seahorse XFe96 Analyzer. After the measurement, supernatant from the cells was removed and the cells were fixed by addition of $100 \mu \mathrm{l}$ methanol (Sigma-Aldrich) for $10 \mathrm{~min}$ at RT and air dried. Subsequently, the cells were stained using crystal violet solution as described for the colony formation assay (see below). For quantification, stained plates were incubated with $200 \mu \mathrm{l}$ of $10 \%$ acetic acid per well with shaking for $15 \mathrm{~min}$ and the resulting solution was analyzed in a plate reader (Tecan GENios plus, Tecan Deutschland GmbH, Crailsheim, Germany) at $630 \mathrm{~nm}$.

\section{Cell proliferation assay}

Adherent growing cells were seeded in 96-well flat bottom plates (TPP) at cell numbers determined for each cell line to reach semiconfluency after 3 days under the respective oxygen and low glucose conditions and to reach confluency after 5 days via preliminary testing. Thus, 250-350 cells per well, depending on the cell line, were seeded in $200 \mu \mathrm{l}$ DMEM/10\%FCS/Gentamycin/ $5 \mathrm{mM}$ glucose. Cell plates were cultured for 5 days at $5 \%$ $\mathrm{CO}_{2}$ and $37{ }^{\circ} \mathrm{C}$ in humidified chambers at oxygen concentrations of 21 or $5 \%$ in hypoxia-incubators (Coy Laboratories Products Inc., Grass Lake, MI, USA) respectively. At least 3 independent wells per cell line were tested either with or without $3 \mathrm{mM} 3-\mathrm{OHB}$ or $1.5 \mathrm{mM}$ acetoacetate (lithium salt) and $\mathrm{LiCl}$ (both Sigma-Aldrich) as control in parallel. Four independent experiments were performed with fresh cultured cell aliquots. At day 5, supernatants were removed for metabolite testing, $100 \mu \mathrm{l}$ of fresh medium containing 5-bromo-2'-deoxyuridine (BrdU) were added for another $24 \mathrm{~h}$, and cell proliferation rate was then analyzed by the BrdU test (Roche; Cell Proliferation ELISA) according to the manufacturer's instructions.

\section{Colony formation assay}

For the colony formation assay, cells were cultured at 100 cells/well in 48 well plates (TTP) with $500 \mu \mathrm{l}$ medium (DMEM/10\% FCS/Gentamycin/5 mM glucose) with or without $3 \mathrm{mM} 3-\mathrm{OHB}$ at oxygen concentrations of 5 or $21 \%$ for 14 to 18 days, depending on the cell line. Half of the medium was replenished every 4 days. Crystal violet staining was performed for evaluation of the adherent colonies. Therefore, supernatant was carefully removed; adherent cells were fixed with $250 \mu \mathrm{l}$ methanol (Sigma-Aldrich) for $10 \mathrm{~min}$ at RT and then dried. Colonies were stained by incubation in crystal violet solution (same as above) for $10 \mathrm{~min}$ and then washed several times with distilled water. Stained colonies were documented by using the ImmunoCapture 6.2 in the ImmunoSpot Analyzer (Cellular Technology, Shaker Heights, OH, USA). Two independent experiments were performed with 8 replicate wells per condition (5 and $21 \%$ oxygen with and without $3-\mathrm{OHB}$ ) for each cell line.

\section{Reverse transcriptase quantitative polymerase chain reaction (RT-qPCR) and Western blotting}

For RT-qPCR and Western blot analyses, aliquots of cells were cultured under the same medium (DMEM/10\% FCS/Gentamycin/5 mM glucose; with or without $3 \mathrm{mM}$ 3 -OHB) and oxygen (21 or $5 \%$ ) conditions to reach subconfluency after 5 days in $75-\mathrm{cm}^{2}$ cell culture flasks.

RNA extraction, cDNA synthesis (iScript, Bio-Rad), and qPCR (Mesa Green containing Meteor Taq hotstart polymerase, Eurogentic) as well as Western blotting were performed as described previously [66]. The primers and conditions of the qPCR are described in Table 2. In brief, qPCR reactions were performed on a 
Table 2 Details of the primer pairs used in this study

\begin{tabular}{llll}
\hline Gene & Forward primer/reverse primer & cDNA size (bp) & PubMed access no. \\
\hline B-Actin & 5'-CCT TGC CAT CCT AAA AGC C-3' & 96 & NM_001101 \\
PPIA & 5'-CAC GAA AGC AAT GCT ATC AC-3' & & NM_021130.3 \\
& 5'-TGT CCA TGG CAA ATG CTG GAC CC-3' & 140 & NM_004051.4 \\
BDH1 & 5'-GCG CTC CAT GGC CTC CAC AA-3' & \\
SCOT & 5'-CGC CGG GTG AAG GCG-3' & 92 & NM_000436.3 \\
5'-GAA TGG CCC AGT TCC TCC C-3' & 99 & NM_000019.3 \\
ACAT1 & 5'-GCC ATT GCC AGT AAG CCA AG-3' & & \\
& 5'-CCA GGC TTT CAC CAA AGC AA-3' & 77 &
\end{tabular}

DNA sequences and PubMed accession numbers for each gene are indicated. qPCR reactions were performed on a CFX96 real-time PCR system (Bio-Rad) operated by CFX Manager Software (version 3.0). The two-step cycler protocol was 5 min at $95{ }^{\circ} \mathrm{C}, 40$ cycles of $15 \mathrm{~s}$ at $95{ }^{\circ} \mathrm{C}, 60 \mathrm{~s}$ at $60{ }^{\circ} \mathrm{C}$, followed by 5 min at $72{ }^{\circ} \mathrm{C}$ and used for all primer pairs

PPIA peptidylprolyl isomerase A, BDH 3-hydroxybutyrate dehydrogenase, SCOT succinyl-CoA transferase (3-oxoacid CoA transferase), $A C A T$ acetyl-CoA-acetyltransferase

CFX96 real-time PCR system (Bio-Rad) operated by CFX Manager Software (version 3.0). The cycler protocol was $5 \mathrm{~min}$ at $95{ }^{\circ} \mathrm{C}$ (initial denaturation), 40 cycles of $15 \mathrm{~s}$ at $95{ }^{\circ} \mathrm{C}, 60 \mathrm{~s}$ at $60{ }^{\circ} \mathrm{C}$ (two-step protocol), and $5 \mathrm{~min}$ at $72{ }^{\circ} \mathrm{C}$ (final extension) for all primer pairs used. Fold expression of genes of interest (Table 2) expression relative to reference genes PPIA and $\beta$-actin was calculated with the $\Delta \Delta \mathrm{Cq}$ method [67]. Post-amplification melting curves were controlled to exclude primer-dimer artifacts and contaminations (not shown). Data from two independent cell culture experiments in triplicate reactions for each primer pair were summarized (Fig. 3b).

For Western blotting, pellets of $1 \times 10^{6}$ tumor cells were lysed and protein concentrations were determined using the Bradford method [68] and Coomassie Brilliant Blue (Roti-Quant; Roth, Karlsruhe, Germany) reagent. Afterwards, samples were mixed with $5 \times$ loading buffer (Fermentas GmbH, St. Leon-Roth, Germany), denatured at $95{ }^{\circ} \mathrm{C}$ for $5 \mathrm{~min}$, chilled on ice, and stored at $-20{ }^{\circ} \mathrm{C}$ for further analysis. Equal amounts of proteins $(20 \mu \mathrm{g})$ were separated on a $10 \%$ polyacrylamide gel. The antibodies used are listed in Table 3 .

\section{Chemosensitivity and radiosensitivity}

For both sensitivity tests, the cells were seeded as in the prior tests in 96-well plates in standard medium with $5 \mathrm{mM}$ glucose and incubated for $48 \mathrm{~h}$ at oxygen concentrations of 5 or $21 \%$ respectively.

For chemosensitivity testing, the test drug concentration (TDC) of epirubicin was defined as $0.5 \mu \mathrm{g} / \mathrm{ml}$, of paclitaxel as $13.6 \mu \mathrm{g} / \mathrm{ml}$, and of carboplatin as $15.8 \mu \mathrm{g} / \mathrm{ml}$, as described in the literature [69-72]. The cell culture medium (see above) with or without $3 \mathrm{mM} 3-\mathrm{OHB}$ and eight different dilutions of the chemotherapeutic drugs (epirubicin: highest concentration: 25\% TDC and twofold dilution series; paclitaxel highest concentration:
$50 \%$ TDC and tenfold dilution series or carboplatin highest concentration: 400\% TDC and twofold dilution series) were added. TDC concentrations for the experiments were selected by cell viability assays performed in preliminary tests with all cell lines (not shown). After 3 days of cell culture, BrdU was added for the final $24 \mathrm{~h}$ of culture and the BrdU test performed as described above.

For radiosensitivity testing, subconfluent monolayers of cells were irradiated in the culture plates filled with $200 \mu \mathrm{l} /$ well with the corresponding growth medium with graded single doses (0-8 Gy) and then cultivated for 10 days at either 5 or $21 \%$ oxygen concentration. Irradiation was performed using a $6 \mathrm{MV}$ Siemens linear accelerator (Siemens, Concord, CA, USA) at a dose rate of $2 \mathrm{~Gy} / \mathrm{min}$. Half of the medium was changed every 4 days. At the end of the incubation period, BrdU was added and cell proliferation was measured by the BrdU test $24 \mathrm{~h}$ thereafter.

\section{Statistics}

Data are presented as means $( \pm$ standard error of mean [SEM]). $p$ values lower than 0.05 in the non-parametric Mann-Whitney $U$ test were considered significant. The software GraphPad Prism 6 (La Jolla, CA 92037 USA) was used to create the figures and to perform statistical analysis. IC50 was determined via the nonlinear regression dose-response curve (inhibition) function of the Prism software.

\section{Results}

Glucose consumption and lactate production is not influenced by 3-OHB

Glucose consumption and production of lactate were normalized to the optical density (OD) of crystal violet dye extracts, which is directly proportional to the cell 
Table 3 Antibodies for Western blot

\begin{tabular}{|c|c|c|c|c|c|c|}
\hline Antibody & Gen/name & Company & Clone & Species & Dilution & MW of antigen \\
\hline \multirow[t]{3}{*}{ Primary } & Beta-actin & Abcam & mAbcam 8226 & Mouse & $1: 10000$ & $42 \mathrm{kDa}$ \\
\hline & Monocarboxylic acid transporter 2 (MCT-2) & Abcam & Polyclonal & Rabbit & $1: 2000$ & $52 \mathrm{kDa}$ \\
\hline & Glucose transporter 1 (GLUT1) & USBiological & Polyclonal & Rabbit & $1: 1000$ & $55 \mathrm{kDa}$ \\
\hline \multirow[t]{2}{*}{ Secondary } & HRP-labeled goat-anti-mouse & KPL & Polyclonal & Goat & $1: 10000$ & \\
\hline & HRP-labeled goat-anti-rabbit & Abcam & Polyclonal & Goat & $1: 20000$ & \\
\hline
\end{tabular}

MW molecular weight

number, as readout for the rate of aerobic glycolysis (Warburg effect) or respiration, respectively. With these measurements, we were able to categorize the metabolic characteristics of the seven tested cell lines as follows: BT20 and MDA-MB 231 exhibit high glucose consumption (with an average of more than $5.0 \mathrm{mM}$ ) normalized to cell number as reflected by OD readout of the crystal violet assay) and high lactate production (with an average of more than $15 \mathrm{mM} / \mathrm{OD})$. HBL100, MCF-7, MDA-MB
468, and T47D consume relatively low amounts of glucose $(<3.5 \mathrm{mM} / \mathrm{OD})$ and show low lactate production (< $10 \mathrm{mM} / \mathrm{OD}$ ), while BT474 show very low levels of glucose consumption $(<1 \mathrm{mM} / \mathrm{OD})$ and lactate production $(<$ $5 \mathrm{mM} / \mathrm{OD}$ ). Interestingly, independent of the respective metabolic characteristics, $3 \mathrm{mM} 3-\mathrm{OHB}$ failed to significantly influence the consumption of glucose or production of lactate in the presence of either 5 or $21 \%$ oxygen (Fig. 1).

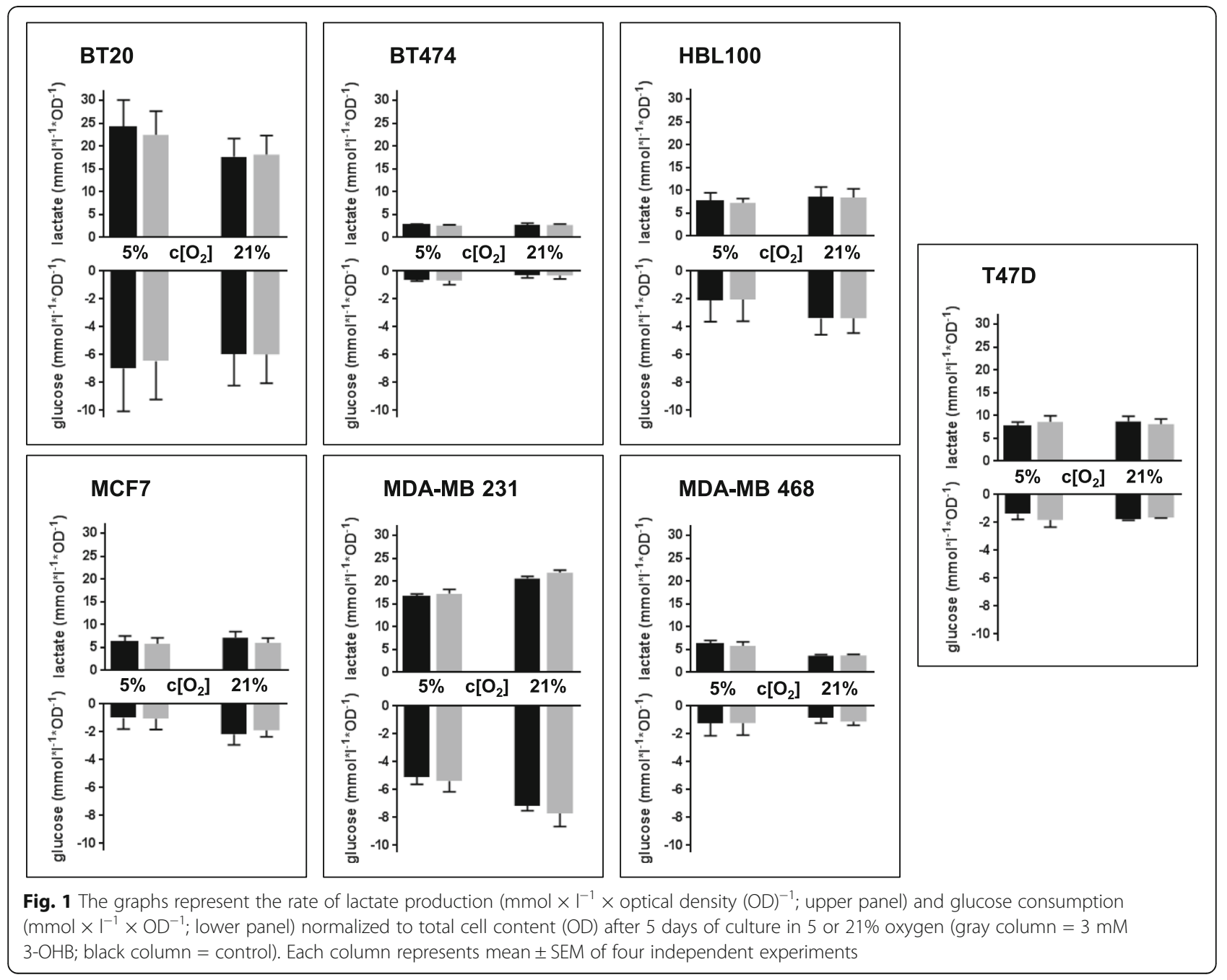


3-OHB changes oxygen consumption rate and extracellular acidification rate in BT20 cells

Seahorse analysis confirmed the metabolic phenotype found in the glucose consumption/lactate production rate analysis. All cell lines except T47D exhibited a more aerobic/energetic cell type, corresponding to cells that divide but generate their energy predominantly from oxidative phosphorylation (OXPHOS) (Fig. 2a).

This basal metabolic phenotype did not correlate with the reaction of these cells to $3-\mathrm{OHB}$, since 3-OHB significantly influenced the oxygen consumption rate (OCR) in BT20 cells only. Here, OCR increased from $77.8 \pm 5.8$ to $124.0 \pm 10.0 \mathrm{pmol} / \mathrm{min}$ (mean $\pm \mathrm{SEM} ; p<0.001$ ), when cells were cultured in the presence of $3-\mathrm{OHB}$ (Fig. 2b, c). For all other cell lines, we found no evidence that $3-\mathrm{OHB}$ influenced oxygen consumption (Fig. 2c, left graph). In addition, the effect of 3-OHB on extracellular acidification rate (ECAR) was analyzed. In the case of BT20 cells, ECAR significantly increased from $61.2 \pm 4.3 \mathrm{mpH}$ (milli $\mathrm{pH}) / \mathrm{min}$ to $80.3 \pm 7.7 \mathrm{mpH} / \mathrm{min}(p<0.05)$ with $3-\mathrm{OHB}$. An increase from $83.6 \pm 3.1 \mathrm{mpH} / \mathrm{min}$ to $99.5 \pm 5.2 \mathrm{mpH} / \mathrm{min}(p<0.05)$ and from $54.2 \pm 1.8$ $\mathrm{mpH} / \mathrm{min}$ to $62.5 \pm 2.3 \mathrm{mpH} / \mathrm{min}(p<0.01)$ was observed in MCF7 and MDA-MB 468 cells under the influence of 3-OHB, respectively (Fig. 2c, right side).

Thus in general, no direct correlation between the metabolic reaction to $3-\mathrm{OHB}$ and the basal energetic phenotype of the cell lines was seen.

\section{Consumption of 3-OHB is not strongly linked to overexpression of ketolytic enzymes and does not correlate with the observed effects on metabolic phenotype}

To investigate whether $\mathrm{BC}$ cells were able to use 3-OHB as a substrate for intermediate metabolism, we next determined uptake rates thereof in the panel of breast cancer cell lines. All cell lines depleted 3-OHB from the culture medium but the magnitude of depletion differed substantially between them (Fig. 3a). Interestingly, we detected variable levels of mRNA expression for key enzymes of ketolysis, namely 3-hydroxybutyrate dehydrogenase 1 (BDH1), succinyl-CoA transferase (SCOT), and acetyl-CoA-acetyltransferase (ACAT), in the seven human breast cancer cell lines (Fig. 3b). In BT474 cells, which showed a relevant consumption of $3-\mathrm{OHB}$ (Fig. 3a), we detected high levels of mRNA for all three key enzymes. SCOT and ACAT, but not BDH1, were overexpressed in HBL100 cells, which showed reduced 3-OHB consumption compared to BT474 cells. All other cell lines revealed low levels of mRNA expression for ketolytic enzymes with a moderate ACAT mRNA expression in MDA-MB 231 and T47D cells. However, changes in mRNA expression levels of ketolytic enzymes in response to $3-\mathrm{OHB}$ and reduced oxygen conditions varied between the tested $\mathrm{BC}$ cell lines. We observed an overall decrease in expression of all three enzymes in MCF7 and MDA-MB 231 cells with further decrease (MCF7) or a moderate increase of BDH1 and ACAT in the presence of 3-OHB. All enzymes were downregulated in HBL100 and MCF7 cells, but and only BDH1 and ACAT in MDA-MB 231 cells in response to low oxygen (5\% oxygen). This regulation was not observed in BT20, BT474, MDA-MB 468, and T47D. In summary, the data show no strong correlation between mRNA overexpression and consumption of $3-\mathrm{OHB}$ or oxygen concentration.

Moreover, the extent of 3-OHB uptake was not linked with the extent of the Warburg effect in each cell line as shown in Fig. 2a. There was also no significant difference in the concentration of $3-\mathrm{OHB}$ remaining in the medium after incubation with cells at 5 or $21 \%$ oxygen (Fig. 3a). By Western blot analysis (Fig. 3c), we showed that MCT2, the key transporter for 3-OHB into cells [27], was expressed highly by all seven cell lines. In particular, MCT2 expression was higher at mild hypoxia in the majority of cell lines. Therefore, the transport of $3-\mathrm{OHB}$ across the plasma membrane seems not to be a limiting factor for 3-OHB consumption by $\mathrm{BC}$ cells. GLUT1 as a key transporter for glucose into tumor cells was detected in all cell lines, and its expression was not influenced by 3-OHB (Fig. 3c). Together, our results demonstrate that $3-\mathrm{OHB}$ does not significantly change the expression of ketolytic enzymes or of the transporter molecules MCT2 and GLUT1. Nevertheless, BC cell lines show marked differences in their ability to deplete 3-OHB from the medium indicating that mRNA expression patterns of ketolytic enzymes were not associated with consumption rate of 3-OHB.

\section{Short-term and long-term cell proliferation of breast cancer cells is not affected by incubation with 3-OHB}

To analyze whether 3-OHB can affect cancer cell proliferation independent of their metabolic phenotype, we incubated the $\mathrm{BC}$ cell lines with $5 \mathrm{mM}$ glucose, with and without addition of $3 \mathrm{mM} \mathrm{3-OHB}$ in the presence of 5 or $21 \%$ oxygen, respectively. Here, we found a slight reduction $(<10 \%)$ in short-term (5 days) proliferation following 3-OHB treatment in BT20, MCF-7, MDA-MB 231, MDA-MB 468, and T47D cells at either oxygen concentration, while BT474 and HBL100 cells were not affected (Fig. 4a). Since AcAc, the second ketone body which rises in circulation upon a ketogenic diet, was described to increase proliferation in BRAF V600E melanoma cells [73], we performed cell proliferation assays in the presence of this metabolite over 5 days in parallel to the 3-OHB experiments. As shown in the Additional file 1, there was no significant effect of AcAc 
A
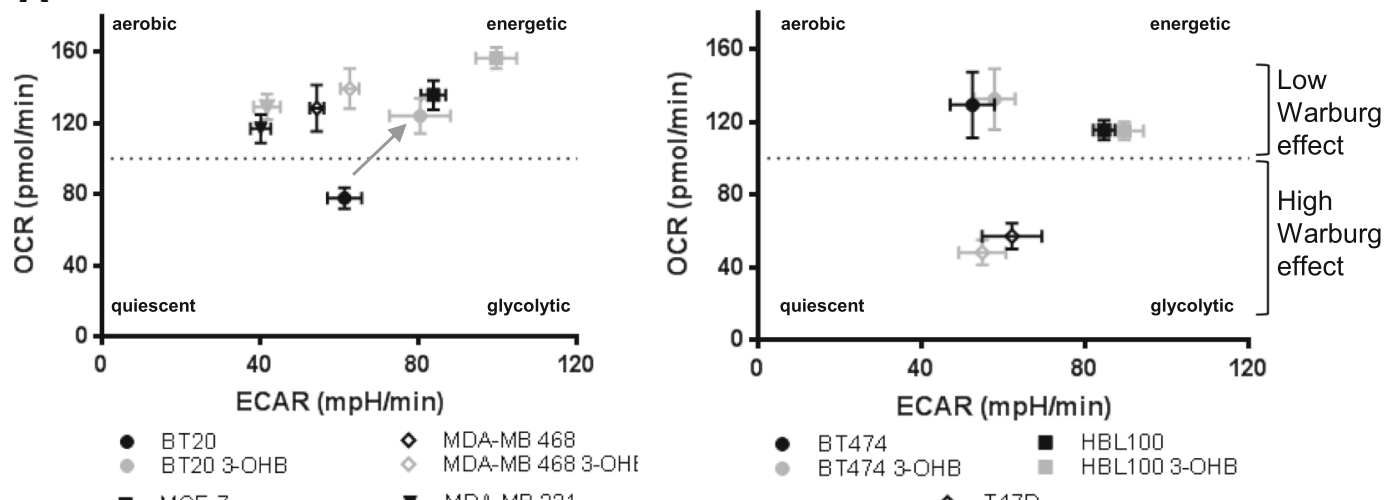

$\diamond \quad$ MDA-MB 468

BT20 3-OHB $\diamond$ MDA-MB 468 3-OHE

$\checkmark$ MDA-MB 231

MCF-7 3-OHE $\nabla$ MDA-MB 231 3-OHI

BT474
BT4743-OHB HBL100
BBL100 3-OHB

$\diamond \quad T 470$

ECAR

B

OCR

BT20
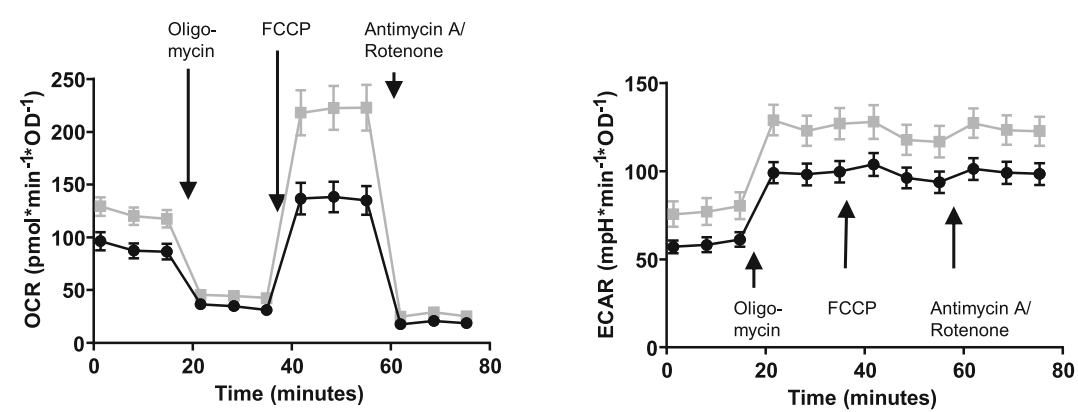

HBL100
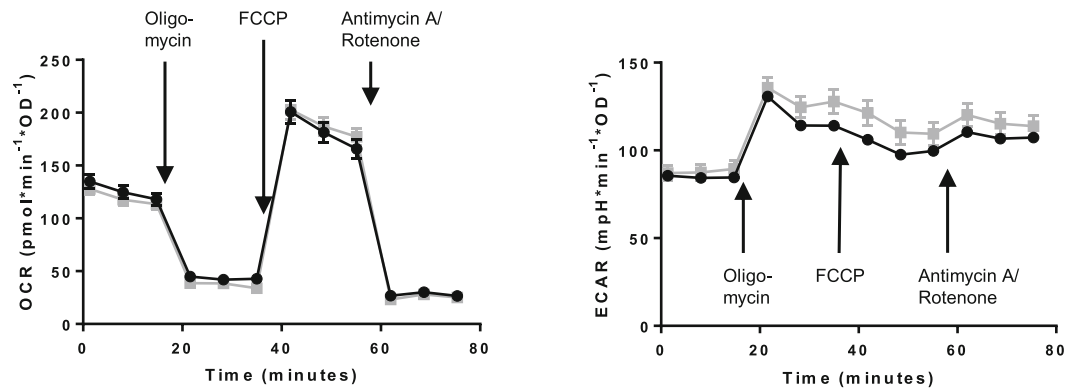

C

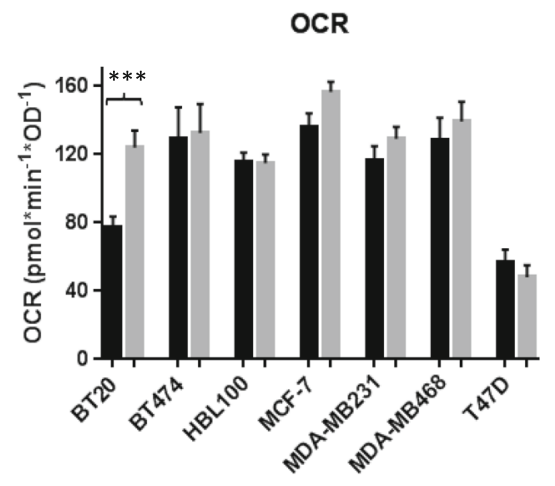

breast cancer cell lines

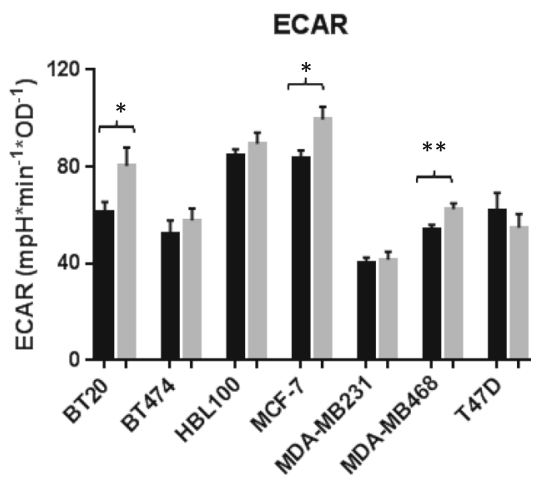

breast cancer cell lines

Fig. 2 (See legend on next page.) 
(See figure on previous page.)

Fig. 2 a Energetic phenotype as revealed by Seahorse flux analysis in cultures without 3-OHB (black symbols) and with 3 mM 3-OHB (gray symbols). Arrow indicates the significant $(p<0.05)$ shift in energetic phenotype observed with the BT20 cell line. Graph summarizes the results of four independent seahorse experiments with four replicate wells for each cell line. $\mathbf{b}$ The curves of OCR and ECAR for the BC cell lines with the most prominent changes (BT20) and without any changes (HBL100) depending on the addition of 3-OHB are shown here. The graph represents the three measuring points of basal levels of respiration/acidification, and changes after addition of oligomycin, FCCP, and antimycin A/rotenone (black line and dots = control, gray line and boxes $=3-\mathrm{OHB}$ ). $\mathbf{c}$ Column statistics of the baseline OCR and ECAR of BC cell lines with 3-OHB (gray column) compared to control (black column) $\left({ }^{* * *} p<0.001 ;{ }^{* *} p<0.01 ;{ }^{*} p<0.05\right)$. Each column summarizes mean \pm SEM of four independent seahorse experiments with four replicate wells per experiment for each cell line

on the proliferation rate of the $\mathrm{BC}$ cell lines tested. A slight increase in proliferation of BT20 cells at 5\% oxygen concentration did not reach statistical significance. Since AcAc was used as lithium salt, control experiments with $\mathrm{LiCl}$ at corresponding $\mathrm{Li}$ concentration were performed, but did not differ from the proliferation rates seen with Li-free cell culture medium (not shown).

To test the effect of $3 \mathrm{mM} \mathrm{3-OHB}$ on long-term proliferation, we performed a colony formation assay for at least 14 days of culture. Similar to the results of the short-term proliferation assay, we found no significant differences in number and size of cell colonies between cultures treated with $3-\mathrm{OHB}$ and control cultures. Of note, oxygen concentration influenced size and number of cell colonies of BT474, HBL100, and MDA-MB 231 cells (Fig. 4b).

\section{3-OHB incubation does not influence the response of BC cells to chemotherapy or ionizing radiation}

We next addressed the question whether exposure to 3-OHB may affect the sensitivity of BC cells to different treatment modalities. We therefore exposed the $\mathrm{BC}$ cell lines to epirubicin, paclitaxel, or carboplatin, three chemotherapeutic agents commonly used in breast cancer treatment. Here, we did not find any significant influence of 3-OHB on the effect of these drugs on cancer cell viability at either 5 or $21 \%$ oxygen (Fig. $5 \mathrm{a}$ and Additional file 2). The cumulative IC50 of paclitaxel was $4.0 \pm 1.1 \mathrm{ng} / \mathrm{ml}$ (mean $\pm \mathrm{SEM}$ ) (control) versus $2.7 \pm$

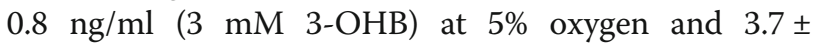
$1.3 \mathrm{ng} / \mathrm{ml}$ (control) versus $3.8 \pm 1.2 \mathrm{ng} / \mathrm{ml}$ (3 mM $3-\mathrm{OHB})$ at $21 \%$ oxygen. The mean cumulative IC50 of epirubicin was $28.3 \pm 6.1 \mathrm{ng} / \mathrm{ml}$ in control cells versus $28.5 \pm 7.8 \mathrm{ng} / \mathrm{ml}(3 \mathrm{mM} \mathrm{3-OHB})$ at $5 \%$ oxygen concentration and $18.9 \pm 3.6 \mathrm{ng} / \mathrm{ml} \mathrm{(control)} \mathrm{versus} 18.0 \pm$ $2.7 \mathrm{ng} / \mathrm{ml}(3 \mathrm{mM} \mathrm{3-OHB})$ at $21 \%$ oxygen concentration. In the case of carboplatin, the mean cumulative IC50 was $6.6 \pm 1.4 \mu \mathrm{g} / \mathrm{ml}$ (control) versus $6.0 \pm 1.4 \mu \mathrm{g} / \mathrm{ml}$ (3-OHB) at $5 \%$ oxygen and $5.0 \pm 2.4 \mu \mathrm{g} / \mathrm{ml}$ (control) versus $4.8 \pm 2.3 \mu \mathrm{g} / \mathrm{ml}(3-\mathrm{OHB})$ at $21 \%$ oxygen concentration. Representative results of the sensitivity tests are shown in Fig. 5b, c.
Further, we found that 3-OHB did not significantly sensitize BC cells to radiation at either 21 or 5\% oxygen. Hypoxia per se, however, showed a tendency to confer a higher radio-resistance to the tumor cells (Fig. $6 a+b$ ) consistent with the known action of oxygen as a radiosensitizer. Two representative examples of dose-response curves are shown for the highest responders to radiation at both oxygen conditions in Fig. $6 \mathrm{c}-\mathrm{f}$. In analyzing the cell lines individually, however, a tendency to confer a higher radiosensitivity is seen for those tumor cells grown in $3-\mathrm{OHB}$ at $5 \%$ oxygen in all but the MDA-MB 321 cell lines (Additional file 3).

\section{Discussion}

In this study, we have shown that beta-hydroxybutyrate (3-OHB), the main ketone body found in the circulation after fasting or ketogenic diets (KDs), was able to change the energetic phenotype of BT20 breast cancer cells when applied at physiological concentrations of $3 \mathrm{mM}$. However, this effect of 3-OHB on energy metabolism was not observed in any of the other BC cell lines investigated herein. Moreover, 3-OHB did not interfere with turnover of glucose and lactate and neither significantly affected short- and long-term cancer cell proliferation, or their sensitivity to chemotherapy or ionizing radiation in any of the cell lines tested. This implies that 3-OHB at a physiological concentration of $3 \mathrm{mM}$ seems to be inert in affecting energetic processes essential for proliferation or cell survival in the tested $\mathrm{BC}$ cell lines in vitro. In addition, we found that AcAc, the second ketone body elevated under a KD, also did not significantly influence proliferation of any $\mathrm{BC}$ cell line measured over 5 days. While preclinical data have shown that AcAc promotes proliferation of BRAF-V600-positive melanoma cells [73], it is interesting that in a pilot study [13] it was a patient with BRAF V600E-positive/BRAF-inhibitor-resistant melanoma who responded favorably to a $\mathrm{KD}$; this highlights the limitations of translating preclinical study results to humans.

This research was performed, since a possible influence of 3-OHB on cancer growth has gained substantial interest over the past years. In particular, different regimes for KDs are currently investigated in several 


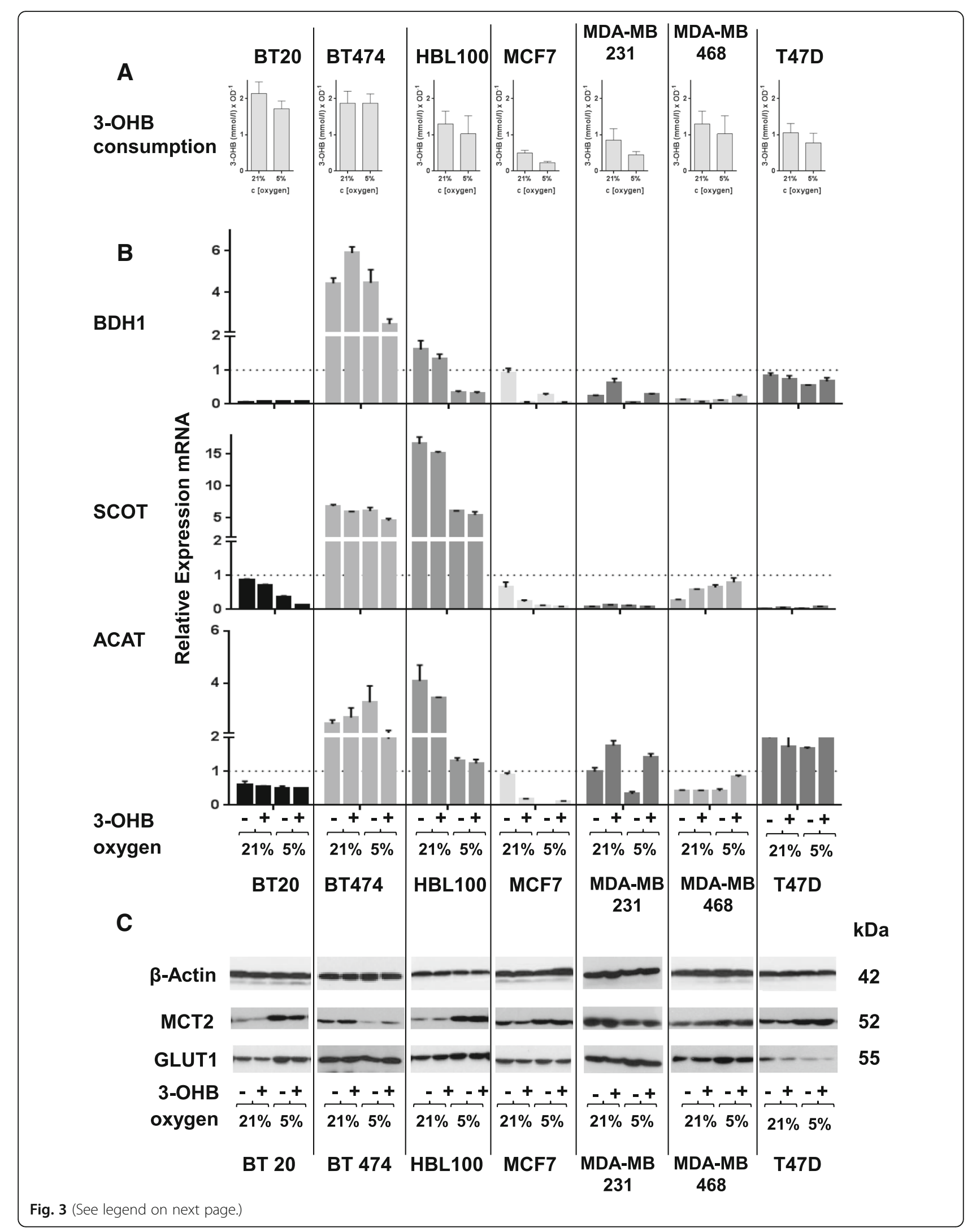


(See figure on previous page.)

Fig. 3 a The columns show the amount of 3-OHB (in mM) consumed by the cells normalized to their cell number as given by optical density (OD) measured with the crystal violet assay. Columns represent mean \pm SEM of two independent experiments with three replicate wells per experiment. There was no significant difference in the consumption of 3-OHB between cultivation at 21 and $5 \%$ oxygen. A tendency to reduced 3-OHB consumption was observed at 5\% oxygen. b Relative expression of mRNA for the ketolytic enzymes BDH1 ( $\beta$-hydroxybutyrate dehydrogenase), SCOT (succinyl-CoA:3-ketoacid coenzyme A transferase), and ACAT (acetyl-CoA acetyltransferases) in the tested BC cell lines. Each column represents mean \pm SEM of data from two independent cell culture experiments in triplicate reactions for each primer pair. c All cell lines express the most important transporter for 3-OHB, the monocarboxylate transporter 2 (MCT2), and the glucose transporter 1 (GLUT1) on protein level. Beta-actin served as loading control. Representative Western blot images of the four test conditions (21 and $5 \%$ oxygen with and without 3-OHB) for each cell line are shown

clinical trials to improve the outcome for cancer patients [74]. Several reports indicate a significant benefit of ketosis and especially $3-\mathrm{OHB}$ on slowing cancer progression in different preclinical cancer models and patients [13, 37, 42, 44, 49, 75-77], amongst them one recent case study successfully applying a KD as part of a multimodal pro-oxidative therapy in a stage IV triple-negative breast cancer patient [78]. On the other hand, there are other publications describing a negative impact of ketosis/3-OHB on tumor cell growth in vitro and in mouse models [35, 36, 79, 80].

Therefore, we initially analyzed the energetic profile of seven different $B C$ cell lines using substrate turnover quantification and energetic flux analysis. The basic energetic
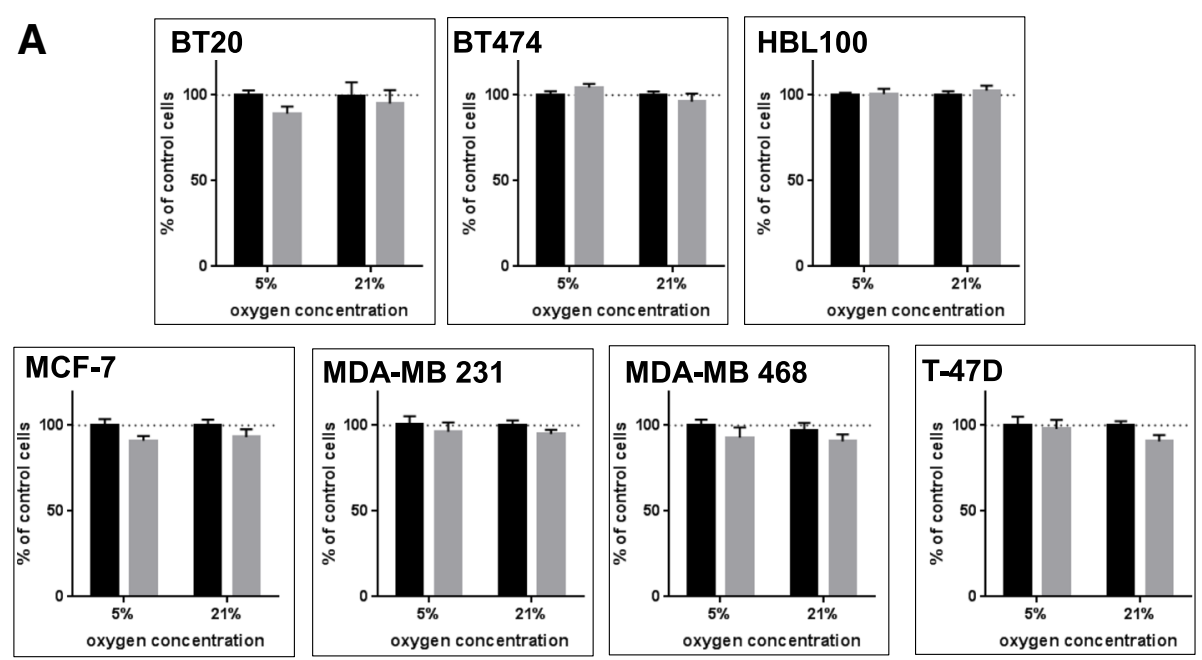

B

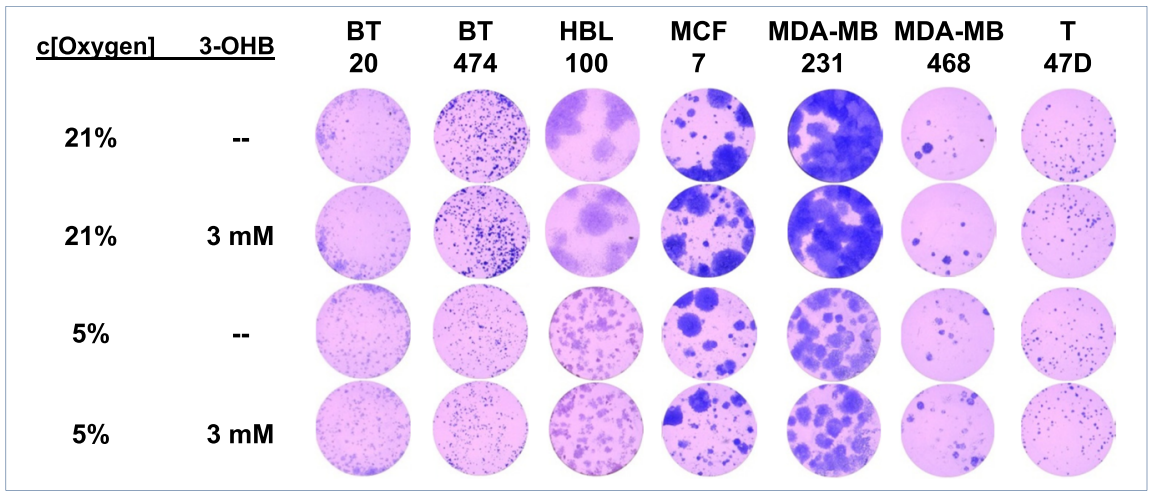

Fig. 4 a The graphs show the proliferation rate (BrdU; in \% of control cells) of the different BC cell lines cultured in medium containing $3 \mathrm{mM}$ 3-OHB (gray column) compared to control without 3-OHB (black column) at 5 or $21 \%$ oxygen concentration after 5 days of culture (differences are not statistically significant). The columns summarize mean \pm SEM of data of four independent experiments with three replicate wells per experiment for each cell line. $\mathbf{b}$ The figure shows representative results (one out of eight replicates for each cell line) of the colony formation assay for the tested BC cell lines after 14 days of culture. The cell lines show no significant alteration in number and size of colonies upon addition of 3-OHB. BT474, HBL-100, and MDA-MB 231 showed an overall reduced colony size at 5\% oxygen concentration compared to $21 \%$ oxygen concentration 


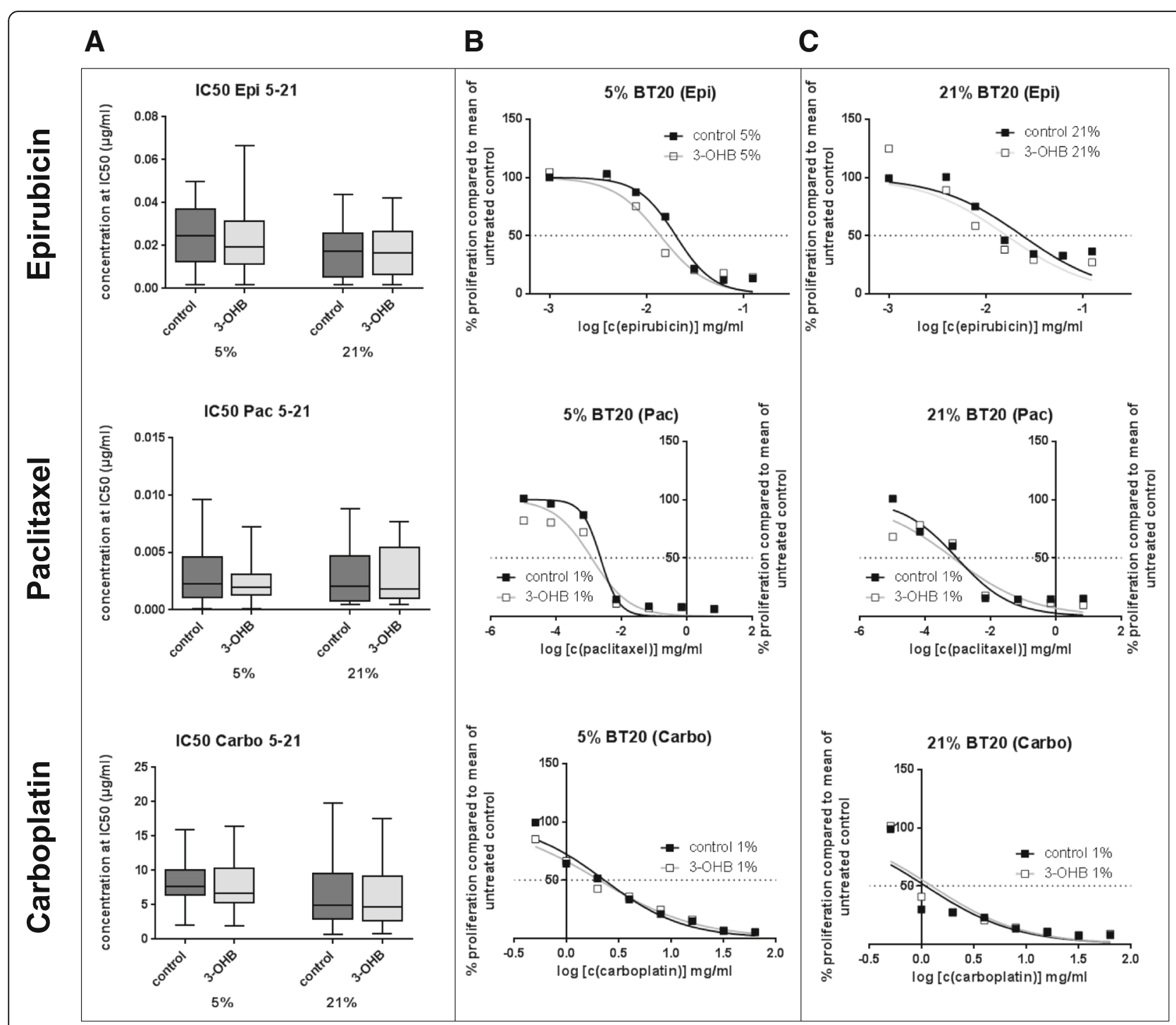

Fig. 5 a The column-graphs show the cumulative IC50 of epirubicin, paclitaxel, and carboplatin in control cells (dark gray box) and cells cultured with $3 \mathrm{mM} 3-\mathrm{OHB}$ (light gray box). Per cell line, three to four each independent dose-response experiments with six replicate wells per experiment were calculated. b Representative dose-response curves obtained for BT-20 cells at 5\% oxygen in chemotherapy sensitivity testing with the chemotherapeutic drugs (epirubicin, paclitaxel, carboplatin) which was used for the calculation of the IC50 (dashed line) (black box = control, white box $=3-\mathrm{OHB}$ ). c Same as b but for $21 \%$ oxygen. Curves summarize four independent experiments with six replicate wells per experiment

phenotypes differed somewhat from the results reported by Pelicano and coworkers [81], who found that triple-negative breast cancer (TNBC) cell lines were in general characterized by a higher extracellular acidification rate (ECAR) and lower oxygen consumption rate (OCR) compared to hormone receptor positive cell lines [81]. For the TNBC cell line BT20, we found an energetic profile that was low in OCR and ECAR and was comparable to the hormone receptor positive T47D cell line. Furthermore, the TNBC cell lines MDA-MB 231 and MDA-MB 468 showed very similar energetic profiles in our experiments and those of Pelicano and colleagues. However, in the study of Pelicano and colleagues, both MDA-MB cell lines were very similar to the energetic phenotype of BT20 cells. In contrast, in our study, the BT20 cells showed a relatively low basal OCR compared to other TNBC cell lines in our experiments. This more oxidative basal phenotype of the TNBC cell line MDA-MB 468 was recently also shown by Lanning and colleagues, even at high glucose conditions of $10 \mathrm{mM}$ [82]. However, this study also described a low oxidative phenotype for the MDA-MB 231 cell line which was remarkably lower than that of MDA-MB 468, while in our investigation, both cell lines showed 


11111111


comparable values of OCR. It is likely that these discrepancies between metabolic profiling data can arise from small differences in the culture conditions, for example different metabolite concentrations in fetal calf serum. Nevertheless, we can conclude that under the experimental conditions used here, only BT20 cells shifted their metabolic profile upon exposure to reduced oxygen concentration. Those discrepancies between our and other metabolic profiling data could also be due to different expression profiles of the cell lines in different laboratories based on different subclones $[83,84]$.

Of note, our quotient of OCR/ECAR for BT20 had a range from 0.9-2.4 (not shown), which is closer to the original findings of Warburg, who found that the quotient of respiration to aerobic glycolysis was $0.3-0.9$ in tumor tissue sections $[8,9]$. Apart from BT20, the other $\mathrm{BC}$ cell lines remained relatively stable with respect to the OCR/ECAR ratio in the presence of 3-OHB.

We found that 3-OHB increases both basic OCR and maximal OCR after inhibition of ATP synthesis by oligomycin and in the presence of the uncoupling agent FCCP in BT20 cells. This indicates that 3-OHB alters mitochondrial capacity, for example, by increasing the expression/activity of respiratory complexes or by inducing mitochondrial biogenesis. In addition, glycolysis was also increased after 3-OHB exposure, indicating an overall increase in metabolic activity of these cells (as displayed in Fig. 2a). However, this phenotype was not observed in the other breast cancer cell lines used in our study. One reason for this difference could be that BT20 is the only TNBC cell line that is mutant for BRCA2 (Table 1). Indeed, a large-scale metabolomics study recently found that BT20 cells differ in their metabolic profile compared to other TNBC cells, based on unsupervised hierarchical clustering [85]. While further experimentation is required to identify the underlying mechanisms for the overall increase in metabolic activity caused by $3-\mathrm{OHB}$ exposure in these cells, our data clearly show that $3-\mathrm{OHB}$ does not affect the viability of BT20 cells or their response to chemotherapy or radiation, despite this metabolic effect. Notably, ECAR is not only dependent on medium acidification via lactic acid but can also be affected by the production of carbonic acid $\left(\mathrm{H}_{2} \mathrm{CO}_{3}\right)$ as an end product of the oxidative degradation of metabolites in the tricarboxylic acid (TCA) cycle $[86,87]$. Here, a very important aspect is the observation that breast cancer cell lines, and especially the TNBC cell lines, often use glutamine as a relevant nutrient to support their metabolic demands [88, 89]. Moreover, glutamine can also be converted to pyruvate and lactate by malic enzyme [90]. Since glutamine is not a limiting factor in our cell culture medium, we cannot exclude that the observed increase in ECAR is due to glutamine metabolism in the cell lines investigated. Therefore, the increase in ECAR in parallel to elevated OCR in BT20 cells is likely to correspond to a generally more "energetic phenotype" of enhanced respiration and $\mathrm{CO}_{2}$ or lactate-induced acidification [86, 87]. Another possible interpretation would be mitochondrial uncoupling via overexpression of uncoupling protein 2 (UCP2) that, although not evaluated in our study, has been shown to occur in BC cell lines [91]. UCP2 overexpression has a metabolic action by supporting glucose and glutamine fermentation at the expense of mitochondrial oxidation [92]. If mitochondrial uncoupling increased, then oxygen consumption would not strictly be linked to respiratory capacity.

Anyway, the shift to a more energetic phenotype seems not to correlate with the metabolism of 3-OHB as an energy source. As proven by RT-qPCR, the BT20 cells express very low levels of mRNA for BDH1, the key entry enzyme of ketolysis, and in line with this, consume only small amounts of 3-OHB. Of note, BT20 cells also displayed the highest basal rate of glucose consumption and lactic acid production of all cell lines tested and this rate was not influenced by $3-\mathrm{OHB}$ at physiological concentrations. Further, the proliferation rate of BT20 cells was unaffected by $3-\mathrm{OHB}$, similar to the other six cell lines tested.

Here, we found no evidence that 3-OHB fuels the metabolism of BC cells in vitro. This is in accordance to an in vivo study, which showed that 3-OHB did not influence growth of melanoma cells either when injected intraperitoneally or when elevated by a high-fat diet [73]. However, at the same time, it is in contrast to a previous study that has shown an increased growth of breast cancer xenografts derived from MDA-MB 231 cells when mice were injected with 3-OHB intraperitoneally [36]. In our in vitro experiments, the MDA-MB 231 cell line showed no increased proliferation in the presence of 3-OHB. Moreover, no notable inhibition of proliferation by $3-\mathrm{OHB}$ could be seen in our short-term ( 5 days) and long-term (at least 14 days) experiments, as described for other cell lines [39-41]. In this context, it should be noted that the growth inhibitory effects for 3-OHB previously reported were predominantly seen with very high and non-physiological concentrations of 3-OHB (5$40 \mathrm{mM}$ ), an observation we have seen in our cell lines as well (not shown). In detail, the first description of an antiproliferative effect of 3-OHB on different cancer cell lines was published by Magee et al. in 1979. The authors tested concentrations of 3-OHB between 10 and $40 \mathrm{mM}$ [39]. In 2009, Skinner et al. described an effect of $3-\mathrm{OHB}$ on the viability of human neuroblastoma cells. Again, the authors used very high concentrations of 3-OHB between 24 and $43 \mathrm{mM}$ [41]. Interestingly, an antiproliferative effect of 3-OHB was also described for a 
physiological concentration of $5 \mathrm{mM} \mathrm{3-OHB}$ in brain tumor cells, but at a very high glucose concentration of $25 \mathrm{mM}$ that represents a more pathophysiological ketoacidotic situation [40]. Our intent was to investigate the effect of 3-OHB in vitro under conditions more likely to be found in cancer patients on KDs. That is why we used physiological concentration of 3-OHB (3 mM) and glucose $(5 \mathrm{mM})$ [22-24]. Using cell culture conditions comparable to our experiments, Martuscelli described an antiproliferative effect of 3-OHB in glioblastoma cell lines and tumor stem cells with half maximal inhibitory concentration (IC50) of $2 \mathrm{mM} \mathrm{3-OHB}$ in the presence of low $(4 \mathrm{mM})$ and physiological $(5-6 \mathrm{mM})$ glucose concentrations [37]. These contrary results described for the effect of 3-OHB on BC cells and glioma cells may reflect differences in their ability to consume 3-OHB.

Previous studies have shown variable gene expression levels of key enzymes involved in ketolytic metabolism in cancer cell lines of different entities [41, 93-97]. In line with these data, we found different mRNA expression patterns of ketolytic enzymes in $\mathrm{BC}$ cell lines. In BT474 and HBL100, mRNA transcripts for all ketolytic enzymes were detectable. This was associated with the highest relative consumption rate of $3-\mathrm{OHB}$ by these cells. In contrast, the other $\mathrm{BC}$ cell lines failed to express increased levels of at least one of these key enzymes. This mRNA expression pattern was independent from the subtype of $\mathrm{BC}$ [59-61] (Table 1) and not influenced by 3 -OHB. In accordance to the results of Antalis and colleagues [98], we found very low mRNA transcripts for ACAT1 for BDH1 in MCF-7 cells, which was linked to their inability to consume 3-OHB. Altogether, the expression of ketolytic enzymes on mRNA level seems not to be associated with the rate of 3-OHB consumption and unrelated to levels of glucose consumption and lactate production; however, we are aware, that mRNA expression did not allow to judge about enzymatic activity.

Cells take up ketone bodies by monocarboxylate transporters (MCTs), a family of proton-linked plasma membrane transporters that carry ketone bodies across biological membranes. The most important transporter for 3-OHB into cancer cells is MCT2 [25, 99-101], and previous studies describe an overexpression of MCT2 in BC cells [102]. Here, we found a strong expression of $\mathrm{MCT} 2$ in all seven $\mathrm{BC}$ cell lines, so that the absence of 3-OHB effects in the cells cannot be explained by defective MCT expression. Since the expression of GLUT1 was found to be related to poor prognosis in breast cancer $[103,104]$, we analyzed if its expression could be reduced by 3-OHB. However, as for MCT2, we could not detect any modulation of the GLUT1 receptor expression in dependency of 3-OHB, an observation also described in cardiomyocytes [105].
The KD is increasing in popularity, and an increasing number of cancer patients are trying the KD simultaneously with chemotherapy and radiation therapy. Recent clinical trials, e.g., NCT01419483, investigate safety and tolerance of a KD during combined chemotherapy and radiation. We analyzed the response of 3-OHB-treated BC cells to chemotherapy and radiation in vitro. No significant changes in the dose-response to three chemotherapeutical drugs most commonly used in $\mathrm{BC}$ treatment [106-110] were observed. Thus, the sensitizing effect of a ketogenic diet on radiochemotherapy in vivo [111] might be mediated by effects other than direct influences on cancer cells. In this context, the clinical study published by Klement and Sweeney [112] is of interest. The authors described an adequate tumor regression for a small cohort of cancer patients undergoing a KD and radiation therapy. Further, two mouse studies with glioma and lung cancer confirm the radio-sensitizing effect of a ketogenic diet $[111,113]$. To date, no information is available on a possible radio-sensitizing effect of 3-OHB. Our in vitro results with $3 \mathrm{mM} 3-\mathrm{OHB}$ indicate a non-significant tendency of this ketone body to sensitize most $\mathrm{BC}$ cells to ionizing radiation.

\section{Conclusions}

The intent of the study was to investigate the effect of 3-OHB on seven $\mathrm{BC}$ cell lines in vitro under conditions likely to be found in patients on a KD or short-term starvation. We have found strong evidence that a physiological concentration of $3 \mathrm{mM} 3-\mathrm{OHB}$ and AcAc did not impact cell proliferation and the response to standard $\mathrm{BC}$ chemotherapy and ionizing radiation is not changed by $3-\mathrm{OHB}$. These findings were independent from the diverse genetic background of the cell lines and differences in mRNA expression of ketolytic enzymes and 3-OHB uptake. Taken together, we found that 3-OHB at physiological concentrations has no major impact on $\mathrm{BC}$ cell proliferative behavior and the metabolic activity in vitro and especially does not fuel tumor cell growth. These results support clinical observations that physiologically increased 3-OHB serum concentrations induced either by a ketogenic diet or by short-term starvation do neither support nor inhibit breast cancer cell proliferation. Thus, a ketogenic diet should be safe for breast cancer patients as already described for patients with diverse cancer types (for review, see [114]).

\section{Additional files}

Additional file 1: The graphs show the proliferation rate (BrdU; in \% of control cells) for the seven different breast cancer cell lines cultured in medium containing $1.5 \mathrm{mM} \mathrm{AcAc}$ (white column) compared to control without AcAc (black column) at $5 \%$ or $21 \%$ oxygen concentration after 5 days of culture (differences are not statistically significant). The columns represent mean \pm SEM of data of 4 independent experiments with 3 replicate wells per experiment for each cell line. (PPTX 104 kb) 
Additional file 2: Graphs present the IC50 with the 95\% confidence intervals for the seven tested cell lines obtained for the three cytostatic drugs epirubicin, paclitaxel and carboplatin comparing the IC50 obtained for cells cultured with $3 \mathrm{mM} 3-\mathrm{OHB}$ (gray blots) with the control cells grown in medium free of 3-OHB (black boxes). Each blot represents 3-4 independent dose-response experiments with 6 replicate wells per experiment. None of the differences are statistically significant; however a strong tendency to a reduction in IC50 of paclitaxel is seen for T47D grown in 3-OHB medium compared to the control. (PPTX $104 \mathrm{~kb}$ )

Additional file 3: Columns represent mean \pm SEM of cell proliferation after irradiation shown for the seven cell lines at 21\% and 5\% oxygen concentration (gray column = with 3-OHB; black column without 3-OHB) (summarized in Fig. 6). The BT20, BT474 and T47D cell lines cultured in the presence of $3-\mathrm{OHB}$ showed a trend towards increased radioresistance at $21 \%$ oxygen (with some significant results at single doses) In contrast, in MCF-7 and MDA-MB 468, 3-OHB cultured cells showed a trend towards impaired cell proliferation following radiation at the same oxygen concentration. At 5\% oxygen concentration, 3-OHB seemed to have a sensitizing effect to radiation in some cell lines. Columns represent mean \pm SEM of 3 independent experiments with 6 replicate wells per experiment. ${ }^{*}<0.05,{ }^{* *} p<0.01,{ }^{* * *} p<0.001$. (PPTX $152 \mathrm{~kb}$ )

\section{Abbreviations}

3-OHB: Beta-hydroxybutyrate; AcAc: Acetoacetate; ACAT: Homo sapiens acetyl-CoA-acetyltransferase; $\mathrm{BDH}$ : 3-Hydroxybutyrate dehydrogenase; BrdU: 5-Bromo-2'-deoxyuridine; CLS: Cell Lines Service GmbH; DMEM: Dulbecco's modified Eagle's medium; ECAR: Extracellular acidification rate; FCS: Fetal calf serum; GLUT1: Glucose transporter 1; KD: Ketogenic diet: MCT: Monocarboxylic acid transporter; $\mathrm{mpH}$ : Milli $\mathrm{pH}$; MW: Molecular weight; OCR: Oxygen consumption rate; OD: Optical density; OXPHOS: Oxidative phosphorylation; PPIA: Peptidylprolyl isomerase A; SCOT: Succinyl-CoA transferase; SEM: Standard error of mean; TDC: Test drug concentration; TNBC: Triple-negative breast cancer

\section{Acknowledgements}

We thank Monika Koospal and Susanne Kolb for the support of the RT-qPCR experiments and Astrid Katzer for the assistance with the radiation.

\section{Funding}

Part of this work was supported by a grant of the Interdisciplinary Centre for Clinical Research (IZKF) University Hospital of Würzburg (Z-2/66 to C.B.).

\section{Availability of data and materials}

The datasets used and/or analyzed during the current study are included in this published article or available from the corresponding author on reasonable request.

\section{Authors' contributions}

$\mathrm{CB}$ and UK originated the study and were responsible for the data collection, analysis, interpretation, and drafting the manuscript. SRJR, JF, AS, CSD, and CO performed the experiments, analyzed the data, and participated in writing the manuscript. RJK and AW helped with editing the manuscript and discussing the data. KB, JW, MS, and MK performed the experiments. All authors read and approved the final manuscript.

\section{Ethics approval and consent to participate}

Not applicable

\section{Competing interests}

The authors declare that they have no competing interests.

\section{Publisher's Note}

Springer Nature remains neutral with regard to jurisdictional claims in published maps and institutional affiliations.

\section{Author details}

'Department of Obstetrics and Gynaecology, University Hospital of Würzburg, Josef-Schneider-Str. 4, 97080 Würzburg, Germany. ${ }^{2}$ Department of Biochemistry and Molecular Biology, Theodor-Boveri-Institute, Biocenter,
University of Würzburg, 97070 Würzburg, Germany. ${ }^{3}$ Department of Radiotherapy and Radiation Oncology, Leopoldina Hospital, 97422 Schweinfurt, Germany. ${ }^{4}$ Department of Radiotherapy, University Hospital of Würzburg, 97080 Würzburg, Germany. ${ }^{5}$ Experimental Surgery, Department of General, Visceral, Vascular, and Pediatric Surgery, University Hospital of Würzburg, 97080 Würzburg, Germany.

\section{Received: 31 August 2017 Accepted: 17 May 2018 \\ Published online: 11 June 2018}

\section{References}

1. DeSantis CE, Fedewa SA, Goding Sauer A, Kramer JL, Smith RA, Jemal A. Breast cancer statistics, 2015: convergence of incidence rates between black and white women. CA Cancer J Clin. 2016;66:31-42.

2. Gnant M, Thomssen C, Harbeck N. St. Gallen/Vienna 2015: a brief summary of the consensus discussion. Breast Care (Basel). 2015;10:124-30.

3. Huang J, Pan G, Jiang H, Li W, Dong J, Zhang H, Ji X, Zhu Z. A meta-analysis between dietary carbohydrate intake and colorectal cancer risk: evidence from 17 observational studies. Biosci Rep. 2017;37

4. Ye Y, Wu Y, Xu J, Ding K, Shan X, Xia D. Association between dietary carbohydrate intake, glycemic index and glycemic load, and risk of gastric cancer. Eur J Nutr. 2017;56:1169-77.

5. van den Brandt PA, Schulpen M. Mediterranean diet adherence and risk of postmenopausal breast cancer: results of a cohort study and meta-analysis. Int J Cancer. 2017;140:2220-31.

6. Palacios C, Daniel CR, Tirado-Gomez M, Gonzalez-Mercado V, Vallejo L, Lozada J, Ortiz A, Hughes DC, Basen-Engquist K. Dietary patterns in Puerto Rican and Mexican-American breast cancer survivors: a pilot study. J Immigr Minor Health. 2017;19:341-8.

7. Augustin LS, Libra M, Crispo A, Grimaldi M, De Laurentiis M, Rinaldo M, D'Aiuto M, Catalano F, Banna G, Ferrau F, et al. Low glycemic index diet, exercise and vitamin D to reduce breast cancer recurrence (DEDiCa): design of a clinical trial. BMC Cancer. 2017;17:69.

8. Warburg O. On respiratory impairment in cancer cells. Science. 1956;124 269-70.

9. Warburg OP, Karl, Negelein E. Über den Stoffwechsel der Carcinomzelle. In: Biochemische Zeitschrift, vol 152; 1924. p. 115-47.

10. Klement RJ, Kammerer U. Is there a role for carbohydrate restriction in the treatment and prevention of cancer? Nutr Metab (Lond). 2011;8:75.

11. Ryu TY, Park J, Scherer PE. Hyperglycemia as a risk factor for cancer progression. Diabetes Metab J. 2014;38:330-6.

12. Monzavi-Karbassi B, Gentry R, Kaur V, Siegel ER, Jousheghany F, Medarametla S, Fuhrman BJ, Safar AM, Hutchins LF, Kieber-Emmons T. Prediagnosis blood glucose and prognosis in women with breast cancer. Cancer Metab. 2016:4:7.

13. Tan-Shalaby JL, Carrick J, Edinger K, Genovese D, Liman AD, Passero VA, Shah RB. Modified Atkins diet in advanced malignancies-final results of a safety and feasibility trial within the Veterans Affairs Pittsburgh Healthcare System. Nutr Metab (Lond). 2016;13:52.

14. Klement RF, Richard D, Gross EC, Champ CE, D'Agostino DP, Fine EJ, Kämmerer U, Poff A, Rho JM, Seyfried TN, Scheck AC. Need for new review of article on ketogenic dietary regimes for cancer patients. Med Oncol. 2017;34:1-4.

15. Schwartz K, Chang HT, Nikolai M, Pernicone J, Rhee S, Olson K, Kurniali PC, Hord NG, Noel M. Treatment of glioma patients with ketogenic diets: report of two cases treated with an IRB-approved energy-restricted ketogenic diet protocol and review of the literature. Cancer Metab. 2015;3:3.

16. Rieger J, Bahr O, Maurer GD, Hattingen E, Franz K, Brucker D, Walenta S, Kammerer U, Coy JF, Weller M, Steinbach JP. ERGO: a pilot study of ketogenic diet in recurrent glioblastoma. Int J Oncol. 2014;44:1843-52.

17. Champ CE, Palmer JD, Volek JS, Werner-Wasik M, Andrews DW, Evans JJ, Glass J, Kim L, Shi W. Targeting metabolism with a ketogenic diet during the treatment of glioblastoma multiforme. J Neuro-Oncol. 2014;117:125-31.

18. Fine EJ, Segal-Isaacson CJ, Feinman RD, Herszkopf S, Romano MC, Tomuta N, Bontempo AF, Negassa A, Sparano JA. Targeting insulin inhibition as a metabolic therapy in advanced cancer: a pilot safety and feasibility dietary trial in 10 patients. Nutrition. 2012;28:1028-35.

19. Schmidt M, Pfetzer N, Schwab M, Strauss I, Kammerer U. Effects of a ketogenic diet on the quality of life in 16 patients with advanced cancer: a pilot trial. Nutr Metab (Lond). 2011:8:54

20. Wheless JW. History of the ketogenic diet. Epilepsia. 2008;49(Suppl 8):3-5. 
21. Laffel L. Ketone bodies: a review of physiology, pathophysiology and application of monitoring to diabetes. Diabetes Metab Res Rev. 1999;15:412-26

22. Pan JW, Rothman TL, Behar KL, Stein DT, Hetherington HP. Human brain beta-hydroxybutyrate and lactate increase in fasting-induced ketosis. $J$ Cereb Blood Flow Metab. 2000;20:1502-7.

23. Cahill GF Jr. Fuel metabolism in starvation. Annu Rev Nutr. 2006;26:1-22.

24. Kim DY, Rho JM. The ketogenic diet and epilepsy. Curr Opin Clin Nutr Metab Care. 2008;11:113-20.

25. Perez-Escuredo J, Van Hee VF, Sboarina M, Falces J, Payen VL, Pellerin L, Sonveaux P: Monocarboxylate transporters in the brain and in cancer. Biochim Biophys Acta 2016, 1863:2481-2497.

26. Halestrap AP. The monocarboxylate transporter family - structure and functional characterization. IUBMB Life. 2012;64:1-9.

27. Broer S, Broer A, Schneider HP, Stegen C, Halestrap AP, Deitmer JW Characterization of the high-affinity monocarboxylate transporter MCT2 in Xenopus laevis oocytes. Biochem J. 1999:341(Pt 3):529-35.

28. Dimmer KS, Friedrich B, Lang F, Deitmer JW, Broer S. The low-affinity monocarboxylate transporter MCT4 is adapted to the export of lactate in highly glycolytic cells. Biochem J. 2000;350(Pt 1):219-27.

29. Newman JC, Verdin E. Beta-hydroxybutyrate: much more than a metabolite. Diabetes Res Clin Pract. 2014;106:173-81.

30. Hashim SA, Vanltallie TB. Ketone body therapy: from the ketogenic diet to the oral administration of ketone ester. J Lipid Res. 2014;55:1818-26.

31. Veech RL, Chance B, Kashiwaya Y, Lardy HA, Cahill GF Jr. Ketone bodies, potential therapeutic uses. IUBMB Life. 2001;51:241-7.

32. Vidali S, Aminzadeh S, Lambert B, Rutherford T, Sperl W, Kofler B, Feichtinger RG. Mitochondria: the ketogenic diet-a metabolism-based therapy. Int J Biochem Cell Biol. 2015;63:55-9.

33. Cahill GF Jr, Veech RL. Ketoacids? Good medicine? Trans Am Clin Climatol Assoc. 2003;114:149-61. discussion 162-143

34. Vaupel P, Kelleher DK, Hockel M. Oxygen status of malignant tumors: pathogenesis of hypoxia and significance for tumor therapy. Semin Oncol. 2001;28:29-35.

35. Martinez-Outschoorn UE, Prisco M, Ertel A, Tsirigos A, Lin Z, Pavlides S, Wang C, Flomenberg N, Knudsen ES, Howell A, et al. Ketones and lactate increase cancer cell "stemness," driving recurrence, metastasis and poor clinical outcome in breast cancer: achieving personalized medicine via Metabolo-Genomics. Cell Cycle. 2011;10:1271-86.

36. Bonuccelli G, Tsirigos A, Whitaker-Menezes D, Pavlides S, Pestell RG, Chiavarina B, Frank PG, Flomenberg N, Howell A, Martinez-Outschoorn UE, et al. Ketones and lactate "fuel" tumor growth and metastasis: evidence that epithelial cancer cells use oxidative mitochondrial metabolism. Cell Cycle. 2010:9:3506-14.

37. Martuscello RT, Vedam-Mai V, McCarthy DJ, Schmoll ME, Jundi MA, Louviere CD, Griffith BG, Skinner CL, Suslov O, Deleyrolle LP, Reynolds BA. A supplemented high-fat low-carbohydrate diet for the treatment of glioblastoma. Clin Cancer Res. 2016:22:2482-95.

38. Shukla SK, Gebregiworgis T, Purohit V, Chaika NV, Gunda V, Radhakrishnan P, Mehla K, Pipinos II, Powers R, Yu F, Singh PK. Metabolic reprogramming induced by ketone bodies diminishes pancreatic cancer cachexia. Cancer Metab. 2014:2:18.

39. Magee BA, Potezny N, Rofe AM, Conyers RA. The inhibition of malignant cell growth by ketone bodies. Aust J Exp Biol Med Sci. 1979;57:529-39.

40. Poff AM, Ari C, Arnold P, Seyfried TN, D'Agostino DP. Ketone supplementation decreases tumor cell viability and prolongs survival of mice with metastatic cancer. Int J Cancer. 2014;135:1711-20.

41. Skinner R, Trujillo A, Ma X, Beierle EA. Ketone bodies inhibit the viability of human neuroblastoma cells. J Pediatr Surg. 2009;44:212-6. discussion 216

42. Klement RJ, Champ CE, Otto C, Kammerer U. Anti-tumor effects of ketogenic diets in mice: a meta-analysis. PLoS One. 2016;11:e0155050.

43. Mavropoulos JC, Buschemeyer WC 3rd, Tewari AK, Rokhfeld D, Pollak M, Zhao Y, Febbo PG, Cohen P, Hwang D, Devi G, et al. The effects of varying dietary carbohydrate and fat content on survival in a murine LNCaP prostate cancer xenograft model. Cancer Prev Res (Phila). 2009;2:557-65.

44. Nebeling LC, Miraldi F, Shurin SB, Lerner E. Effects of a ketogenic diet on tumor metabolism and nutritional status in pediatric oncology patients: two case reports. J Am Coll Nutr. 1995;14:202-8.

45. Otto C, Kaemmerer U, Illert B, Muehling B, Pfetzer N, Wittig R, Voelker HU, Thiede A, Coy JF. Growth of human gastric cancer cells in nude mice is delayed by a ketogenic diet supplemented with omega-3 fatty acids and medium-chain triglycerides. BMC Cancer. 2008;8:122.

46. Poff AM, Ari C, Seyfried TN, D'Agostino DP. The ketogenic diet and hyperbaric oxygen therapy prolong survival in mice with systemic metastatic cancer. PLoS One. 2013;8:e65522.

47. Seyfried TN, Sanderson TM, El-Abbadi MM, McGowan R, Mukherjee P. Role of glucose and ketone bodies in the metabolic control of experimental brain cancer. Br J Cancer. 2003;89:1375-82.

48. Zuccoli G, Marcello N, Pisanello A, Servadei F, Vaccaro S, Mukherjee P, Seyfried TN. Metabolic management of glioblastoma multiforme using standard therapy together with a restricted ketogenic diet: case report. Nutr Metab (Lond). 2010;7:33.

49. Csaba Toth ZC. Halted progression of soft palate cancer in a patient treated with the paleolithic ketogenic diet alone: a 20-months follow-up. Am J Med Case Rep. 2016:4:288-92.

50. Rodrigues LM, Uribe-Lewis S, Madhu B, Honess DJ, Stubbs M, Griffiths JR. The action of beta-hydroxybutyrate on the growth, metabolism and global histone $\mathrm{H} 3$ acetylation of spontaneous mouse mammary tumours: evidence of a beta-hydroxybutyrate paradox. Cancer Metab. 2017;5:4

51. Klement RJ. The influence of ketogenic therapy on the 5 R's of radiobiology Int J Radiat Biol. 2017:1-13.

52. Paoli A, Bianco A, Grimaldi KA, Lodi A, Bosco G. Long term successful weight loss with a combination biphasic ketogenic Mediterranean diet and Mediterranean diet maintenance protocol. Nutrients. 2013;5:5205-17.

53. Paoli A, Cenci L, Grimaldi KA. Effect of ketogenic Mediterranean diet with phytoextracts and low carbohydrates/high-protein meals on weight, cardiovascular risk factors, body composition and diet compliance in Italian council employees. Nutr J. 2011;10:112.

54. Zajac A, Poprzecki S, Maszczyk A, Czuba M, Michalczyk M, Zydek G. The effects of a ketogenic diet on exercise metabolism and physical performance in off-road cyclists. Nutrients. 2014;6:2493-508.

55. Urbain P, Strom L, Morawski L, Wehrle A, Deibert P, Bertz H. Impact of a 6-week non-energy-restricted ketogenic diet on physical fitness, body composition and biochemical parameters in healthy adults. Nutr Metab (Lond). 2017;14:17

56. Dashti HM, Mathew TC, Hussein T, Asfar SK, Behbahani A, Khoursheed MA Al-Sayer HM, Bo-Abbas YY, Al-Zaid NS. Long-term effects of a ketogenic diet in obese patients. Exp Clin Cardiol. 2004;9:200-5.

57. Perez-Guisado J, Munoz-Serrano A, Alonso-Moraga A. Spanish ketogenic Mediterranean diet: a healthy cardiovascular diet for weight loss. Nutr J. 2008;7:30.

58. Vaupel P, Schlenger K, Knoop C, Hockel M. Oxygenation of human tumors: evaluation of tissue oxygen distribution in breast cancers by computerized O2 tension measurements. Cancer Res. 1991;51:3316-22.

59. Holliday DL, Speirs V. Choosing the right cell line for breast cancer research. Breast Cancer Res. 2011;13:215.

60. Neve RM, Chin K, Fridlyand J, Yeh J, Baehner FL, Fevr T, Clark L, Bayani N, Coppe JP, Tong F, et al. A collection of breast cancer cell lines for the study of functionally distinct cancer subtypes. Cancer Cell. 2006;10:515-27.

61. Subik K, Lee JF, Baxter L, Strzepek T, Costello D, Crowley P, Xing L, Hung MC, Bonfiglio T, Hicks DG, Tang P. The expression patterns of ER, PR, HER2, CK5/6, EGFR, Ki-67 and AR by immunohistochemical analysis in breast cancer cell lines. Breast Cancer (Auckl). 2010:4:35-41.

62. Dai X, Cheng H, Bai Z, Li J. Breast cancer cell line classification and its relevance with breast tumor subtyping. J Cancer. 2017:8:3131-41.

63. Baenke F, Dubuis S, Brault C, Weigelt B, Dankworth B, Griffiths B, Jiang M, Mackay A, Saunders B, Spencer-Dene B, et al. Functional screening identifies MCT4 as a key regulator of breast cancer cell metabolism and survival. J Pathol. 2015;237:152-65.

64. Smith SE, Mellor P, Ward AK, Kendall S, McDonald M, Vizeacoumar FS, Vizeacoumar FJ, Napper S, Anderson DH. Molecular characterization of breast cancer cell lines through multiple omic approaches. Breast Cancer Res. 2017;19:65.

65. Catalogue of somatic mutations in cancer. (https://cancer.sanger.ac.uk/cosmic).

66. Kammerer U, Gires O, Pfetzer N, Wiegering A, Klement RJ, Otto C. TKTL1 expression in human malign and benign cell lines. BMC Cancer. 2015;15:2.

67. Pfaffl MW. A new mathematical model for relative quantification in real-time RT-PCR. Nucleic Acids Res. 2001:29:e45.

68. Bradford MM. A rapid and sensitive method for the quantitation of microgram quantities of protein utilizing the principle of protein-dye binding. Anal Biochem. 1976;72:248-54. 
69. Chang J, Lee A, Lee J, Lim W, Sung SH, Moon Bl. Correlation between the molecular subtype of breast cancer and the in vitro adenosine triphosphatebased chemosensitivity assay. J Korean Surg Soc. 2013;84:313-20.

70. Lin Y, Lv F, Liu F, Guo X, Fan Y, Gu F, Gu J, Fu L. High expression of pyruvate kinase $M 2$ is associated with chemosensitivity to epirubicin and 5-fluorouracil in breast cancer. J Cancer. 2015;6:1130-9.

71. Kurbacher CM, Mallmann P, Kurbacher JA, Hübner H, Krebs D. Chemosensibilitätstestungen in der gynäkologischen Onkologie: Erfahrungen mit einem ATP-Biolumineszenzassay. Geburtshilfe Frauenheilkd. 1996:56:70-8.

72. Gwe Ahn S, Ah Lee S, Woo Lee H, Min Lee H, Jeong J. In vitro chemoresponse assay based on the intrinsic subtypes in breast cancer. Jpn J Clin Oncol. 2014:44:624-31.

73. Xia S, Lin R, Jin L, Zhao L, Kang HB, Pan Y, Liu S, Qian G, Qian Z, Konstantakou E, et al. Prevention of dietary-fat-fueled ketogenesis attenuates BRAF V600E tumor growth. Cell Metab. 2017;25:358-73.

74. NCT01865162 N, NCT02983942, NCT02939378, NCT03160599, NCT01754350, NCT02516501, NCT03075514, NCT01535911 (www.clinicaltrials.gov).

75. Branca JJ, Pacini S, Ruggiero M. Effects of pre-surgical vitamin D supplementation and ketogenic diet in a patient with recurrent breast cancer. Anticancer Res. 2015;35:5525-32.

76. Jansen $\mathrm{N}$, Walach $\mathrm{H}$. The development of tumours under a ketogenic diet in association with the novel tumour marker TKTL1: a case series in general practice. Oncol Lett. 2016;11:584-92.

77. Schwalb MTM, Hines S, Reinwald H, Ruggiero M. Clinical observation of a novel, complementary, immunotherapeutic approach based on ketogenic diet, chondroitin sulfate, vitamin D 3, oleic acid and a fermented milk and colostrum product. Am J Immunol. 2016;12:91-8.

78. Iyikesici MS, Slocum AK, Slocum A, Berkarda FB, Kalamian M, Seyfried TN. Efficacy of metabolically supported chemotherapy combined with ketogenic diet, hyperthermia, and hyperbaric oxygen therapy for stage IV triple-negative breast cancer. Cureus. 2017;9:e1445

79. Martinez-Outschoorn UE, Lin Z, Whitaker-Menezes D, Howell A, Lisanti MP, Sotgia F. Ketone bodies and two-compartment tumor metabolism: stromal ketone production fuels mitochondrial biogenesis in epithelial cancer cells. Cell Cycle. 2012;11:3956-63.

80. Martinez-Outschoorn UE, Lin Z, Whitaker-Menezes D, Howell A, Sotgia F, Lisanti MP. Ketone body utilization drives tumor growth and metastasis. Cell Cycle. 2012;11:3964-71.

81. Pelicano H, Zhang W, Liu J, Hammoudi N, Dai J, Xu RH, Pusztai L, Huang P. Mitochondrial dysfunction in some triple-negative breast cancer cell lines: role of mTOR pathway and therapeutic potential. Breast Cancer Res. 2014;16:434.

82. Lanning NJ, Castle JP, Singh SJ, Leon AN, Tovar EA, Sanghera A, MacKeigan JP, Filipp FV, Graveel CR. Metabolic profiling of triplenegative breast cancer cells reveals metabolic vulnerabilities. Cancer Metab. 2017:5:6

83. Chatterjee R. Cell biology. Cases of mistaken identity. Science. 2007;315:928-31.

84. Chatterjee R. Cell biology. When 60 lines don't add up. Science. 2007;315:929.

85. Dubuis S, Baenke F, Scherbichler N, Alexander LT, Schulze A, Zamboni N. Metabotypes of breast cancer cell lines revealed by non-targeted metabolomics. Metab Eng. 2017;43:173-86.

86. Mookerjee SA, Brand MD. Measurement and analysis of extracellular acid production to determine glycolytic rate. J Vis Exp. 2015:e53464.

87. Mookerjee SA, Goncalves RL, Gerencser AA, Nicholls DG, Brand MD. The contributions of respiration and glycolysis to extracellular acid production. Biochim Biophys Acta. 2015;1847:171-81.

88. Wise DR, Thompson CB. Glutamine addiction: a new therapeutic target in cancer. Trends Biochem Sci. 2010;35:427-33.

89. Lampa M, Arlt H, He T, Ospina B, Reeves J, Zhang B, Murtie J, Deng G, Barberis C, Hoffmann D, et al. Glutaminase is essential for the growth of triple-negative breast cancer cells with a deregulated glutamine metabolism pathway and its suppression synergizes with mTOR inhibition. PLoS One. 2017;12:e0185092.

90. DeBerardinis RJ, Mancuso A, Daikhin E, Nissim I, Yudkoff M, Wehrli S, Thompson CB. Beyond aerobic glycolysis: transformed cells can engage in glutamine metabolism that exceeds the requirement for protein and nucleotide synthesis. Proc Natl Acad Sci U S A. 2007;104:19345-50.

91. Fine EJ, Miller A, Quadros EV, Sequeira JM, Feinman RD. Acetoacetate reduces growth and ATP concentration in cancer cell lines which overexpress uncoupling protein 2. Cancer Cell Int. 2009;9:14.
92. Vozza A, Parisi G, De Leonardis F, Lasorsa FM, Castegna A, Amorese D, Marmo R, Calcagnile VM, Palmieri L, Ricquier D, et al. UCP2 transports C4 metabolites out of mitochondria, regulating glucose and glutamine oxidation. Proc Natl Acad Sci U S A. 2014;111:960-5.

93. Chang HT, Olson LK, Schwartz KA. Ketolytic and glycolytic enzymatic expression profiles in malignant gliomas: implication for ketogenic diet therapy. Nutr Metab (Lond). 2013;10:47.

94. Matsumoto K, Fujiwara $Y$, Nagai R, Yoshida M, Ueda S. Expression of two isozymes of acyl-coenzyme A: cholesterol acyltransferase-1 and -2 in clear cell type renal cell carcinoma. Int J Urol. 2008;15:166-70.

95. Maurer GD, Brucker DP, Bahr O, Harter PN, Hattingen E, Walenta S, MuellerKlieser W, Steinbach JP, Rieger J. Differential utilization of ketone bodies by neurons and glioma cell lines: a rationale for ketogenic diet as experimental glioma therapy. BMC Cancer. 2011;11:315.

96. Patel MS, Russell JJ, Gershman H. Ketone-body metabolism in glioma and neuroblastoma cells. Proc Natl Acad Sci U S A. 1981;78:7214-8.

97. Sawai M, Yashiro M, Nishiguchi Y, Ohira M, Hirakawa K. Growth-inhibitory effects of the ketone body, monoacetoacetin, on human gastric cancer cells with succinyl-CoA: 3-oxoacid CoA-transferase (SCOT) deficiency. Anticancer Res. 2004;24:2213-7.

98. Antalis CJ, Arnold T, Rasool T, Lee B, Buhman KK, Siddiqui RA. High ACAT1 expression in estrogen receptor negative basal-like breast cancer cells is associated with LDL-induced proliferation. Breast Cancer Res Treat. 2010;122:661-70.

99. Benton CR, Campbell SE, Tonouchi M, Hatta H, Bonen A. Monocarboxylate transporters in subsarcolemmal and intermyofibrillar mitochondria. Biochem Biophys Res Commun. 2004;323:249-53.

100. Pinheiro C, Reis RM, Ricardo S, Longatto-Filho A, Schmitt F, Baltazar F. Expression of monocarboxylate transporters 1, 2, and 4 in human tumours and their association with CD147 and CD44. J Biomed Biotechnol. 2010; 2010:427694.

101. Valenca I, Pertega-Gomes N, Vizcaino JR, Henrique RM, Lopes C, Baltazar F, Ribeiro D. Localization of MCT2 at peroxisomes is associated with malignant transformation in prostate cancer. J Cell Mol Med. 2015;19:723-33.

102. Cheng C, Edin NF, Lauritzen KH, Aspmodal I, Christoffersen S, Jian L, Rasmussen LJ, Pettersen EO, Xiaoqun G, Bergersen LH. Alterations of monocarboxylate transporter densities during hypoxia in brain and breast tumour cells. Cell Oncol (Dordr). 2012;35:217-27.

103. Eilertsen M, Andersen S, Al-Saad S, Kiselev Y, Donnem T, Stenvold H, Pettersen I, Al-Shibli K, Richardsen E, Busund LT, Bremnes RM. Monocarboxylate transporters 1-4 in NSCLC: MCT1 is an independent prognostic marker for survival. PLoS One. 2014;9:e105038.

104. Macheda ML, Rogers S, Best JD. Molecular and cellular regulation of glucose transporter (GLUT) proteins in cancer. J Cell Physiol. 2005;202:654-62.

105. Tardif A, Julien N, Pelletier A, Thibault G, Srivastava AK, Chiasson JL, Coderre L. Chronic exposure to beta-hydroxybutyrate impairs insulin action in primary cultures of adult cardiomyocytes. Am J Physiol Endocrinol Metab. 2001;281:E1205-12.

106. Bria E, Nistico C, Cuppone F, Carlini P, Ciccarese M, Milella M, Natoli G, Terzoli E, Cognetti F, Giannarelli D. Benefit of taxanes as adjuvant chemotherapy for early breast cancer: pooled analysis of 15,500 patients. Cancer. 2006;106:2337-44.

107. Kern P, Kalisch A, von Minckwitz G, Putter C, Kolberg HC, Pott D, Kurbacher C, Rezai M, Kimmig R. Neoadjuvant, anthracycline-free chemotherapy with carboplatin and docetaxel in triple-negative, early-stage breast cancer: a multicentric analysis of rates of pathologic complete response and survival. J Chemother. 2016;28:210-7.

108. Shao N, Wang S, Yao C, Xu X, Zhang Y, Zhang Y, Lin Y. Sequential versus concurrent anthracyclines and taxanes as adjuvant chemotherapy of early breast cancer: a meta-analysis of phase III randomized control trials. Breast. 2012;21:389-93.

109. Sharma P, Lopez-Tarruella S, Garcia-Saenz JA, Ward C, Connor CS, Gomez HL, Prat A, Moreno F, Jerez-Gilarranz Y, Barnadas A, et al. Efficacy of neoadjuvant carboplatin plus docetaxel in triple-negative breast cancer: combined analysis of two cohorts. Clin Cancer Res. 2017;23:649-57.

110. Turner N, Biganzoli L, Di Leo A. Continued value of adjuvant anthracyclines as treatment for early breast cancer. Lancet Oncol. 2015;16:e362-9.

111. Allen BG, Bhatia SK, Buatti JM, Brandt KE, Lindholm KE, Button AM, Szweda LI, Smith BJ, Spitz DR, Fath MA. Ketogenic diets enhance oxidative stress and radio-chemo-therapy responses in lung cancer xenografts. Clin Cancer Res. 2013;19:3905-13. 
112. Klement RJ, Sweeney RA. Impact of a ketogenic diet intervention during radiotherapy on body composition: I. Initial clinical experience with six prospectively studied patients. BMC Res Notes. 2016;9:143.

113. Abdelwahab MG, Fenton KE, Preul MC, Rho JM, Lynch A, Stafford P, Scheck AC. The ketogenic diet is an effective adjuvant to radiation therapy for the treatment of malignant glioma. PLoS One. 2012;7:e36197.

114. Klement RJ. Beneficial effects of ketogenic diets for cancer patients: a realist review with focus on evidence and confirmation. Med Oncol. 2017;34:132

Ready to submit your research? Choose BMC and benefit from:

- fast, convenient online submission

- thorough peer review by experienced researchers in your field

- rapid publication on acceptance

- support for research data, including large and complex data types

- gold Open Access which fosters wider collaboration and increased citations

- maximum visibility for your research: over $100 \mathrm{M}$ website views per year 